\title{
A new species of Agelas from the Zanzibar Archipelago, western Indian Ocean (Porifera, Demospongiae)
}

\author{
Renata Manconi', Roberto Pronzato², Erica Perino ${ }^{2}$ \\ I Dipartimento di Scienze della Natura e del Territorio (Dip.Ne.T.), Università di Sassari, Via Muroni 25, \\ I-07100, Sassari, Italy 2 Dipartimento di Scienze della Terra dell'Ambiente e della Vita (Di.S.T.A.V.), Corso \\ Europa 26, I-16132 Genova, Italy
}

Corresponding author: Renata Manconi (r.manconi@uniss.it)

Academic editor: M. Pfannkuchen | Received 2 April 2015 | Accepted 25 September 2015 | Published 14 January 2016

http://zoobank.org/C90A2838-2151-46A1-9C94-33C5B6389089

Citation: Manconi R, Pronzato R, Perino E (2016) A new species of Agelas from the Zanzibar Archipelago, western Indian Ocean (Porifera, Demospongiae). ZooKeys 553: 1-31. doi: 10.3897/zookeys.553.5999

\begin{abstract}
A new sponge species (Demospongiae: Agelasida: Agelasidae) is described from the eastern coast of Unguja Island in the Zanzibar Archipelago. Agelas sansibarica sp. n. is compared to all other Agelas species described so far. The new species differs from its congeners mainly in its three categories of verticillate spicules (acanthostyles, acanthostrongyles, and acanthoxeas) and their sizes. Acanthostrongyles, well represented in the spicular complement, are an exclusive trait of the new species widening the morphological range of the genus. Summarizing on spicular complement and spicular morphotraits of 36 species belonging to the genus Agelas: i) 32 species show only acanthostyles from Indo-Pacific $(n=14)$, Atlantic $(\mathrm{n}=17)$, and Mediterranean $(\mathrm{n}=1)$; ii) three Indo-Pacific species show acanthostyles and acanthoxeas; iii) one species $A$. sansibarica sp. $\mathbf{n}$. from the western Indian Ocean is characterised by the unique trait of three categories of verticillate spicules (acanthostyles, acanthostrongyles and acanthoxeas). A key for the IndoPacific species is supplied together with short descriptions, illustrations, and geographic range; literature on chemical bioprospecting of the genus Agelas is also provided.
\end{abstract}

\section{Keywords}

Biodiversity, sponges, morpho-taxonomy, diagnostic key, geographic range, Unguja Island 


\section{Introduction}

The sponge fauna of the Zanzibar Archipelago is poorly studied and data are reported almost exclusively in very old papers (Lendenfeld 1897, Baer 1906, Jenkin 1908, Sollas 1908, Thomas 1976). In none of these papers species belonging to the genus Agelas Duchassaing \& Michelotti, 1864 (Porifera: Demospongiae: Agelasida: Agelasidae) are reported. The presence of Agelas mauritiana (Carter, 1883) along the Zanzibar coasts was recently recorded (Said et al. 2010) as producer of bioactive compounds.

The widespread genus Agelas, including until now 35 valid species, was established by Duchassaing and Michelotti (1864: 76) describing the type species Agelas dispar from the Caribbean Sea. Agelas oroides is the only Mediterranean species, and is endemic. The western Atlantic (Gulf of Mexico, Caribbean, and Brazil) hosts 17 species. The majority of the latter (13) were recently revised while the remaining four species were considered dubious or suggested as synonyms (Van Soest 2002, Muricy et al. 2011, Parra-Velandia et al. 2014).

The Indo-Pacific species of Agelas number 18, including the new species here described. The most widespread species is Agelas mauritiana (including its oxeata variety) recorded in the Australian western Pacific, and the Indian Ocean from the Mascarenes Archipelago (type locality), Seychelles Archipelago, Madagascar, and Mozambique Channel to the southern Red Sea and east to Sri Lanka.

Several species (14) are reported only once from the type locality i.e. Agelas axifera Hentschel, 1911; A. bispiculata Vacelet, Vasseur \& Lévi, 1976; A. braekmani Thomas, 1998 (1997); A. carpenteri (Gray, 1867); A. cavernosa Thiele, 1903; A. citrina Gotera \& Alcolado, 1987; $A$. dendromorpha Lévi, 1993; A. inaequalis Pulitzer-Finali, 1986; $A$. linnaei de Voogd, Parra-Velandia \& Van Soest, 2008; A. nakamurai Hoshino, 1985; A. nemoechinata Hoshino, 1985; A. novaecaledoniae Lévi \& Lévi, 1983; A. robusta, Pulitzer-Finali 1982; A. semiglaber Pulitzer-Finali, 1996.

In the framework of sponges, applied research on bioactive compounds at a global level (e.g. Murray et al. 2013) focuses on Agelas species as producers of interesting molecules e.g. A. clathrodes, A. linnaei, A. mauritiana, A. nakamurai, A. oroides, and A. sceptrum (Walker et al. 1981, Fathi-Afshar et al. 1989, Keifer et al. 1991, Braekman et al. 1992, Bernan et al. 1993, König and Wright 1993, Chanas et al. 1996, König et al. 1998, Eder et al. 1999, Assmann et al. 2000, 2001, 2004, Fattorusso and Taglialatela-Scafati 2000, Assmann and Köck 2002, Fujita et al. 2003, Bickmeyer et al. 2004, 2005, 2008, Bickmeyer 2005, Costantino et al. 2006, Meketa and Weinreb 2006, Ferretti 2006, Vik et al. 2006, Ding et al. 2007, Ferretti et al. 2007, 2009, Vergne et al. 2008, Hertiani et al. 2010, Said et al. 2010, Regalado et al. 2011, Mordhorst et al. 2015). In this scenario of intensive bioprospecting, research knowledge of systematics and taxonomy in depth is a key tool to identify and define the status of specimens/biomaterial to be processed.

The present paper aims to report the discovery of a new species of Agelas from the Zanzibar Archipelago comparing it to all species belonging to the genus. To support global sharing of information on faunistics and taxonomy of Porifera from not widely accessible data sources an updated overview on the morphology and geographic distribution of 
Agelas species from the Indo-Pacific area is also provided together with a brief description and exhaustive iconography, as well as a dichotomous key to Indo-Pacific species.

\section{Materials and methods}

Representative fragments of six sponge specimens from the Unguja Island were studied. Growth form, surface traits, skeletal architecture, shape and size of the spicules are considered diagnostic morphotraits. Spicule dimensions are given as maximum, minimum, and medium lengths and widths of $c a .400$ spicules.

The skeletal architecture was investigated by hand-cut sections of the ectosome and choanosome. To study the three-dimensional arrangements of fibres and spicules in the skeleton, fragments ca. $10 \times 10 \times 2 \mathrm{~mm}$ were cut, cleaned with $5 \%$ sodium hypochlorite $(\mathrm{NaClO})$ for $24 \mathrm{~h}$ in a warm temperature $\left(35-40{ }^{\circ} \mathrm{C}\right)$, then washed and stirred five times in abundant double distilled water, washed and stirred twice in ethanol 95\%, and finally allowed to air dry and gold-sputtered or mounted in Eukitt. The skeletal samples were than studied by light microscope (LM) and scanning electron microscope (SEM). Spicule preparations were made by dissolving a small fragment of the specimen in 65\% boiling nitric acid $\left(\mathrm{HNO}_{3}\right)$ and cleaned spicules were rinsed four times with water, once with $95 \%$ ethanol. The spicules were air-dried on slides, mounted in Eukitt, and observed by a Leitz Dialux 20 EB (LM), as well as on aluminium stubs and coated with gold for the observation with a Vega3 TESCAN type LMU (SEM).

Specimens were deposited at the Museo civico di Storia Naturale "Giacomo Doria" of Genoa, Italy (acronym MSNG). For the taxonomy of genus and species level the Systema Porifera (Hooper and Van Soest 2002) and the World Porifera Database (Van Soest et al. 2015) are considered as reference.

\section{Systematic account}

Phylum Porifera Grant, 1835

Class Demospongiae Sollas, 1885

Order Agelasida Hartman, 1980

Family Agelasidae Verrill, 1907

Genus Agelas Duchassaing \& Michelotti, 1864

Chalinopsis Schmidt, 1870 (junior synonym)

Ectyon Gray, 1867 (junior synonym)

Oroidea Gray, 1867 (junior synonym)

Pachychalinopsis Schmidt, 1880 (nomen nudum)

Siphonochalinopsis Schmidt, 1880 (nomen nudum)

Diagnosis (emended from Van Soest 2002, p. 820). Massive-lobate, encrusting, tubular, branching or flabellate sponges, often of considerable size, with smooth to finely 
conulose surfaces provided with small rounded and/or key-hole shaped apertures. Colour usually orange or brownish-orange. Consistency toughly compressible, firm. No ectosomal specialization. Choanosomal skeleton isotropic or anisotropic, occasionally irregular, network of primary ascending spongin fibres and secondaries. Main fibres mostly cored by megascleres. Main and interconnecting fibres echinated by megascleres in most cases. Spicules as verticillate styles, or styles and oxeas, or styles, oxeas and strongyles. Biogeographic pattern of 36 nominal species mostly matches tropical waters, a single species occurs in the Mediterranean. The genus has not been recorded from the eastern Pacific, West Africa, and the northern Atlantic European coasts.

\section{Agelas sansibarica Perino \& Pronzato, sp. n.}

http://zoobank.org/7F8E3929-DD8D-4991-A8E0-C391C89AC1D0

Figs $1-5$

Material examined. Holotype: MSNG 57991 (A30), 70\% ethanol, Jambiani $\left(06^{\circ} 18^{\prime} 44.8^{\prime \prime S}, 39^{\circ} 33^{\prime} 32^{\prime \prime E}\right)$, eastern coast of Unguja Island, Zanzibar Archipelago, United Republic of Tanzania, SCUBA diving, 4.vii.2010, leg. Mr. Okala. Paratypes: MSNG 57992, MSNG 57993, MSNG 57994, MSNG 57995, MSNG 57996 (A12, A26, A27, A28, A29, respectively) ibid.

Diagnosis. Agelas with unique spicular complement composed of three spicular categories, oxeas, styles and strongyles with spines arranged in a variable number of verticilles.

Etymology. The speciphic epithet refers to the Zanzibar Archipelago.

Habitat. Coral reef, quite common at 7-12 m of depth. Water temperature 28$31{ }^{\circ} \mathrm{C}$. Salinity 20-36\%o (Fryday 2011). As reported by the Swiss Marine NGO manager of the local sponge farming facility (Jambiani Lagoon) the new species is massively farmed (Christian Vaterlaus, pers. comm., 2010).

Geographic distribution. Western Indian Ocean, but only recorded from the type locality to date.

Description. Growth form massive, thick, rounded, 6-10 cm in diameter. Colour in life purple to orange and light brown. Consistency firm and elastic. Surface rough to the touch, finely hispid, finely conulose for tips of ascending fibres supporting the dermal membrane, with regularly scattered circular and convoluted depressions $(0.5$ $\mathrm{cm}$ in diameter) very similar to those of $A$. cerebrum. Oscules few, small, irregularly scattered. Choanosomal skeleton as an irregularly reticulate network of spongin fibres. Primary fibres $50-110(71.67 \pm 17.63) \mu \mathrm{m}$ in diameter, strongly echinate by single, scattered spicules to groups of diverging spicules; ascending primary fibres cored by spicules also present. Secondary fibres 20-50 (35 \pm 9$) \mu \mathrm{m}$ in diameter notably echinate and cored by spicules. Tertiary network not observed.

Megascleres as three categories of monaxons mostly with acute spines. Acanthostyles $90-250(180.72 \pm 28.66) \times 7.5-20(13.46 \pm 2.59) \mu \mathrm{m}$ ornate by verticillate spines arranged as $11-27(17.8 \pm 2.86)$ whorls. Acanthoxeas $130-295(195 \pm 43.09)$ 


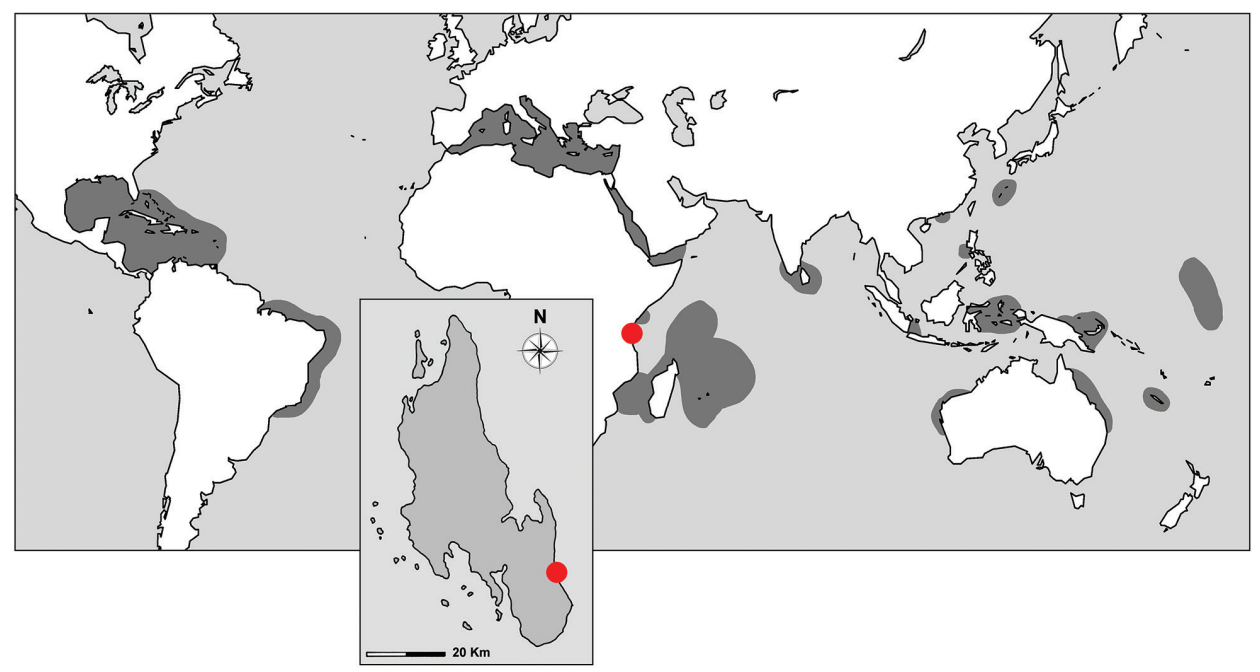

Figure I. Genus Agelas. Biogeographic pattern (grey areas). The red dot indicates the type locality of the new species Agelas sansibarica sp. n. at Jambiani (06 $\left.18^{\prime} 44.8^{\prime \prime S}, 39^{\circ} 33^{\prime} 32^{\prime \prime E}\right)$, eastern coast of Unguja Island, Zanzibar Archipelago, United Republic of Tanzania.

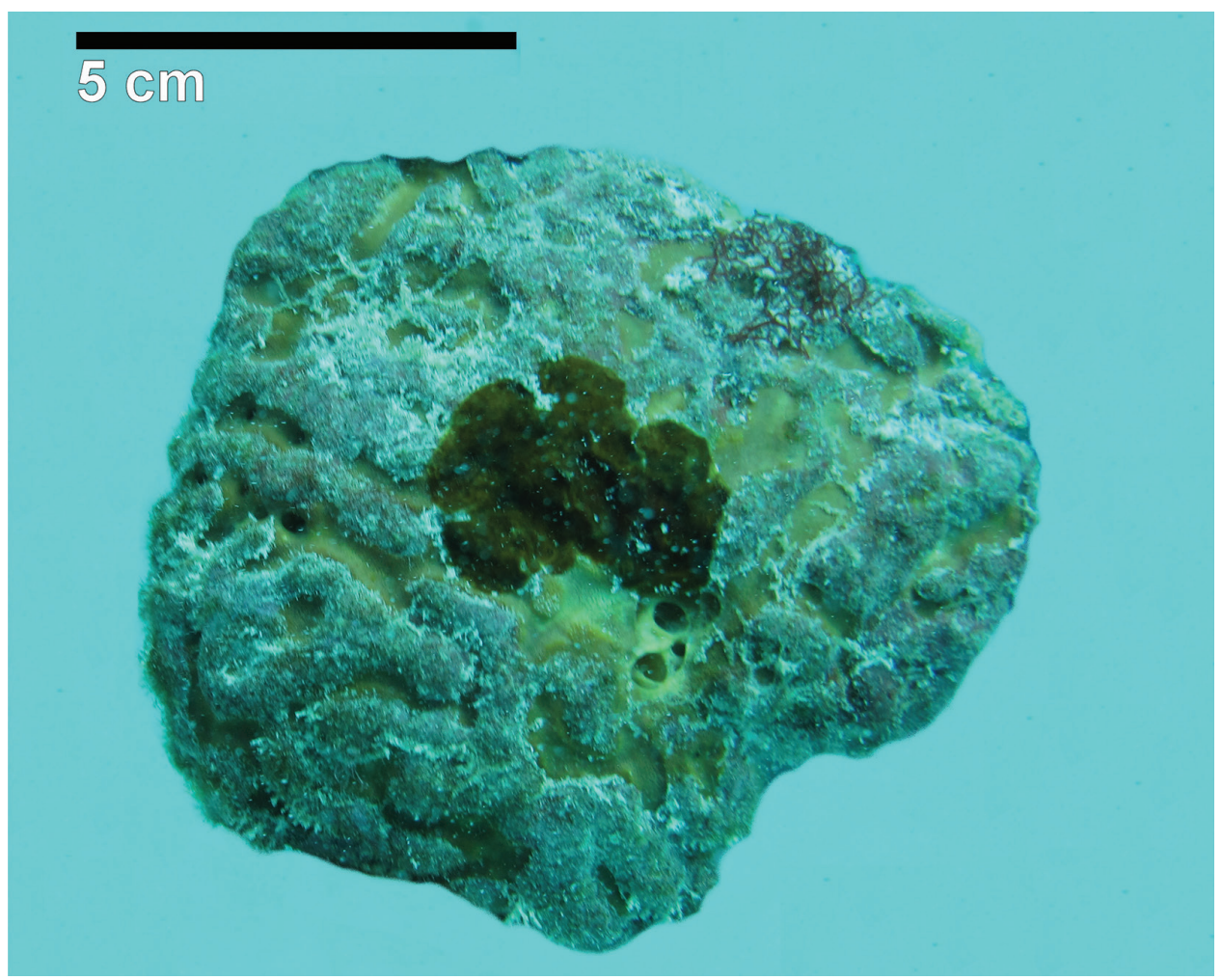

Figure 2. Agelas sansibarica sp. n. Type specimen (alcohol preserved, colour different from in vivo) from the Zanzibar Archipelago. 


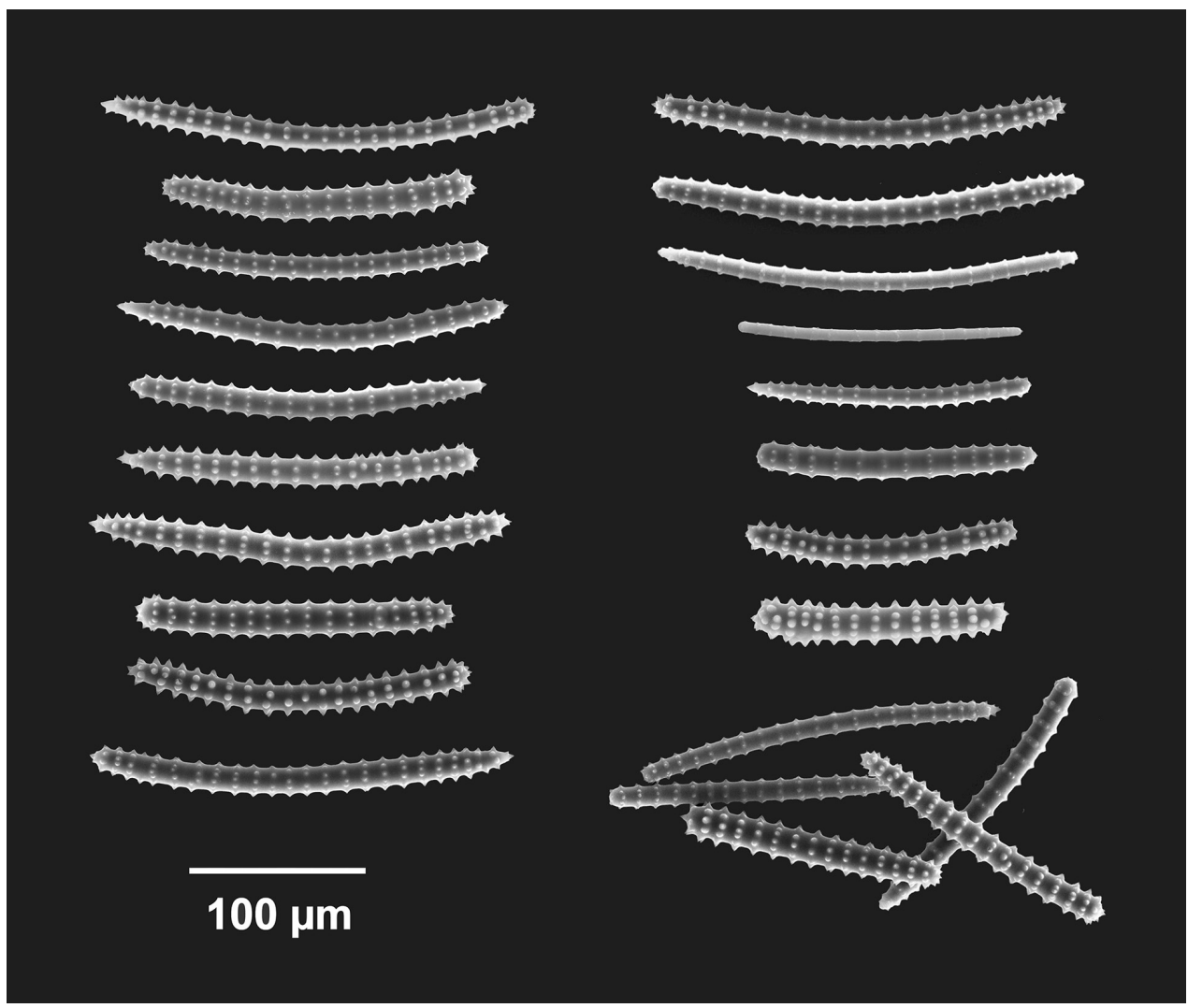

Figure 3. Agelas sansibarica sp. n. Spicular complement of verticillate acanthostyles, acanthoxeas and acanthostrongyles (SEM).

$\times 7.5-15(12.17 \pm 1.89) \mu \mathrm{m}$ ornate by verticillate spines arranged as 14-26 (19.24 \pm 3.47) whorls. Acanthostrongyles 80-245 (148.18 \pm 36.82) × 4-17 (11.09 \pm 4.24$) \mu \mathrm{m}$ ornate by verticillate spines arranged as 9-26 (15.76 \pm 3.85$)$ whorls. Annulate spicules apparently young.

Remarks. The new species is characterized by the co-presence of three categories of spicules never recorded in other Agelas species. Acanthostrongyles are abundant, ca. $20-30 \%$ of the total number of spicules.

\section{Discussion}

\section{Geographic range of Indo-Pacific Agelas species}

Madagascar, Mozambique Channel, Seychelles and Mascarene archipelagos (Western Indian Ocean province) harbour four species, whereas Japan (Ryukyu Archipelago) and New Caledonia enumerates two species each. Only one species each is recorded 


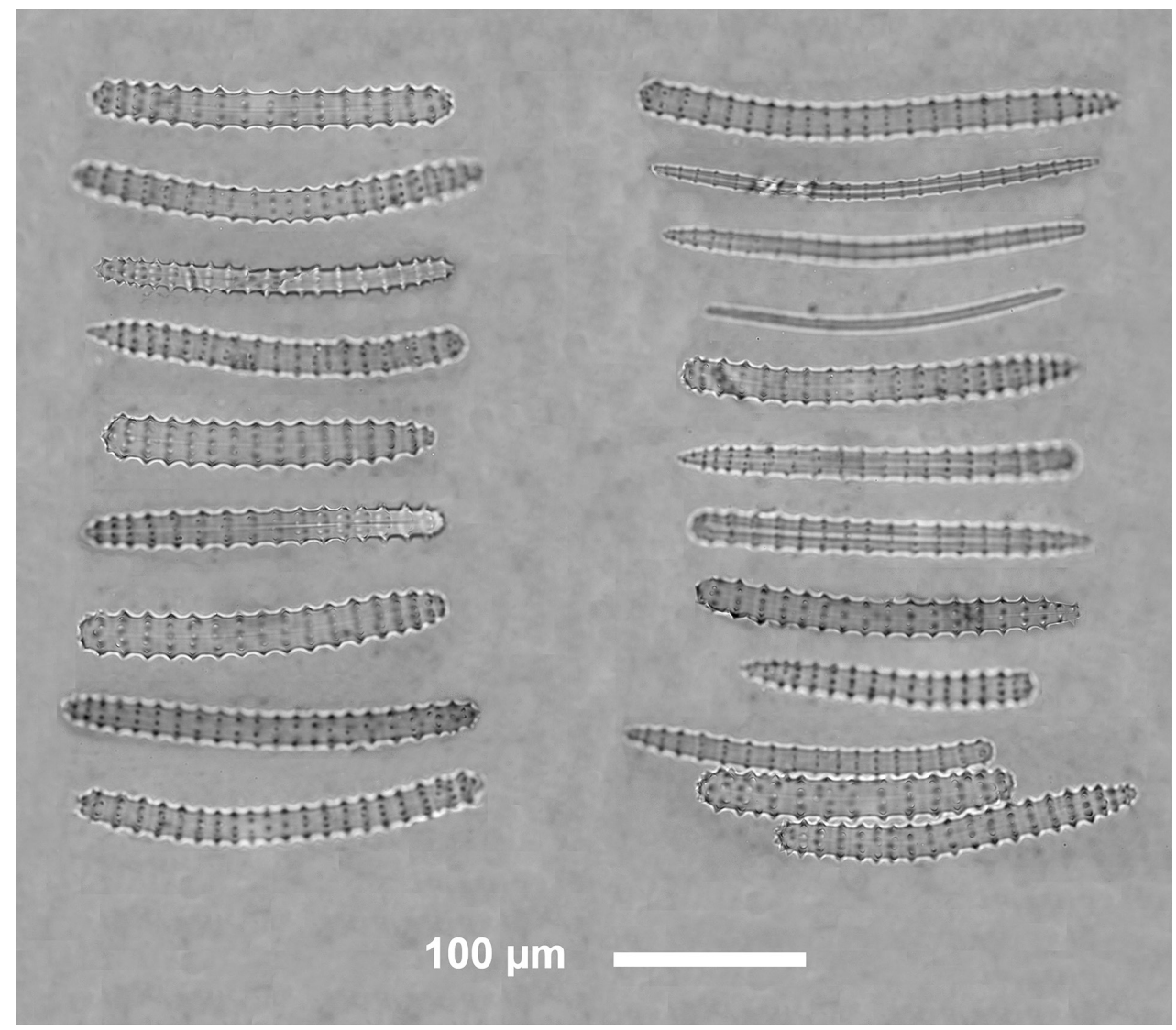

Figure 4. Agelas sansibarica sp. n. Spicular complement of verticillate acanthostyles, acanthoxeas and acanthostrongyles (LM).

from Philippines, Papua New Guinea, and Funafuti. Only one species each is harboured in the Red Sea/Gulf of Aden, Sri Lanka, Moluccas, Sunda Shelf/Java Sea (Indonesia), Hong Kong, Funafuti, and Australia (Fig. 1).

\section{Diagnostic morphotraits comparative analysis of Agelas Indo-Pacific species}

To discriminate between all 36 Agelas species by diverging diagnostic morphotraits is notably difficult, as highlighted in the previous section. Morphotraits of the genus are extremely conservative and different species appear very similar. Focusing on the IndoPacific species our attempt was not as completely successful as is also the case for the Atlantic species by Parra-Velandia et al. (2014).

Atlanto-Mediterranean Agelas species (18) seems to possess only acanthostrongyles, including the uncertain $A$. fascicularis, A. flabelliformis, $A$. inaequalis, and $A$. rudis not redescribed by Parra-Velandia et al. (2014). 


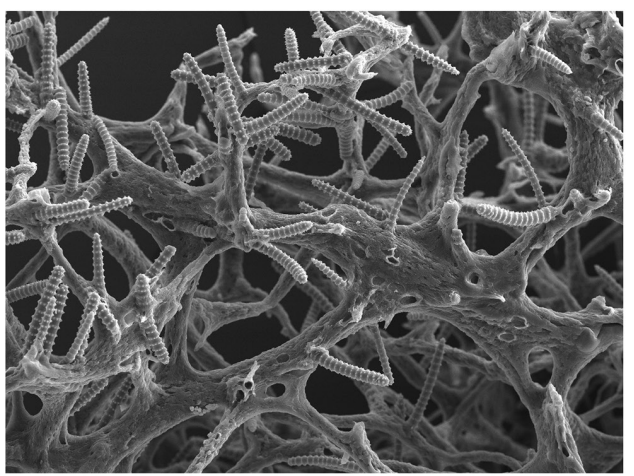

a

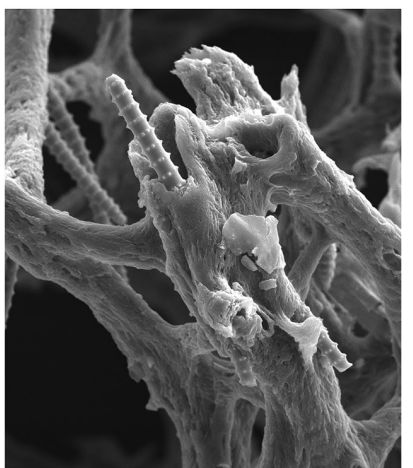

C $100 \mu \mathrm{m}$
$200 \mu \mathrm{m}$

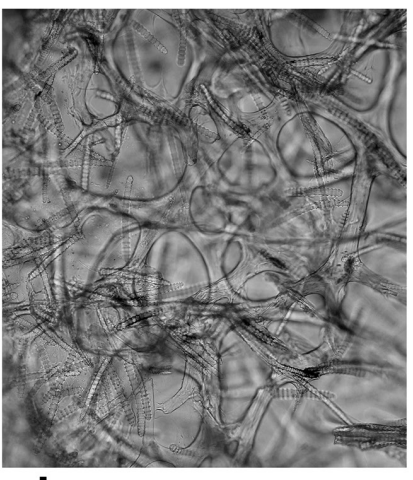

$200 \mu \mathrm{m}$

b

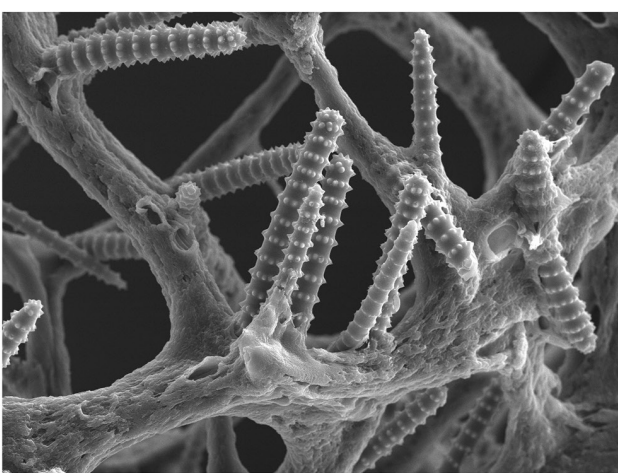

$100 \mu \mathrm{m}$

Figure 5. Agelas sansibarica sp. n. a skeletal network of spongin fibres echinated by spicules (SEM) b detail of fibres surface echinated by verticillate spicules (SEM) c section of a primary fibre cored by a verticillate acanthostrongyle d-e skeletal network (LM).

Among the 17 previously known Indo-Pacific Agelas species, the spicular complement of 14 species is composed of acanthostyles in a single or two-dimensional classes (see Appendix 1, Figs 6-21 for details).

The most common and studied Indo-Pacific species, i.e. A. mauritiana, are characterized by a single spicular type acanthostyles, which are extremely variable in morphology, abundance of spines, and dimensional range (sometime more than three times in length) (see Table 1). The Atlantic $A$. dispar and the Mediterranean $A$. oroides show a similar size variability of acanthostyles. Only the Indo-Pacific $A$. axifera, $A$. mauritiana var. oxeata, and $A$. novaecaledoniae show two different categories of spicules, i.e. acanthostyles and acanthoxeas.

The new species $A$. sansibarica is characterized by the unique morphotrait of three categories of megascleres, i.e. acanthostyles, acanthoxeas, and acanthostrongyles with spines arranged in verticilles regularly scattered along the entire spicule. No other Agelas species exhibit this spicular combination. Acanthostrongyles, well identifiable and abundant, represent an exclusive diagnostic trait of the new species. The functional 
Table I. Agelas mauritiana. Morphometries and morphotraits by different authors.

\begin{tabular}{|c|c|c|c|c|c|}
\hline References & Acanthostyles $\mu \mathrm{m}$ & \begin{tabular}{|c|}
$\begin{array}{c}\text { Whorls } \\
\text { no }^{\circ}\end{array}$ \\
\end{tabular} & Colour & $\begin{array}{l}\text { Habitus size } \\
\text { (cm) }\end{array}$ & Consistency \\
\hline Carter 1883 & 132 & $15-18$ & - & - & - \\
\hline Thiele 1903 & $200 \times 14-15$ & 16 & - & - & - \\
\hline Dendy 1905 & $176 \times 16$ & - & $\begin{array}{c}\text { dark } \\
\text { brown }\end{array}$ & $\begin{array}{l}\text { tubular } \\
3.1 \times 1.6 \text { length } \\
\times \text { diameter }\end{array}$ & $\begin{array}{l}\text { firm } \\
\text { resilient }\end{array}$ \\
\hline Laubenfels 1954 & $170-180 \times 10-14$ & $12-18$ & - & - & - \\
\hline Lévi 1961 & $150-160 \times 8-12$ & $16-20$ & brown & $\begin{array}{l}\text { massive } \\
6-10 \times 4\end{array}$ & $\begin{array}{l}\text { firm } \\
\text { resilient } \\
\text { soft }\end{array}$ \\
\hline Lévi 1964 & $275 \times 12-13$ & $15-17$ & - & - & - \\
\hline Lévi 1967 & $140-230 \times 8-10$ & $10-15$ & - & - & - \\
\hline Vacelet and Vasseur 1965 & $135-250$ & $13-20$ & - & - & - \\
\hline Vacelet and Vasseur 1971 & $80-180 \times 7.5-12.5$ & $18-23$ & brown & $\begin{array}{c}\text { encrusting } \\
1.6-1.5 \\
\text { thickness }\end{array}$ & $\begin{array}{c}\text { firm } \\
\text { resilient } \\
\text { coriaceus }\end{array}$ \\
\hline Thomas 1979 & $112-212 \times 6-8$ & $6-8$ & $\begin{array}{c}\text { pale } \\
\text { yellow }\end{array}$ & $\begin{array}{l}\text { encrusting } \\
\text { cavernous }\end{array}$ & $\begin{array}{c}\text { firm } \\
\text { resilient } \\
\text { compressible }\end{array}$ \\
\hline
\end{tabular}

role of acanthostrongyles is doubled since echinanting spicules arm both the fibres surface and the core of the axial part of fibres.

Summarizing spicular complements and spicular morphotraits of 36 Agelas species: i) 32 species show only acanthostyles from Atlantic (17), Mediterranean (1), and the majority (14) of the Indo-Pacific areas; ii) three Indo-Pacific species show acanthostyles and acanthoxeas; iii) only one species $A$. sansibarica sp. n. from the western Indian Ocean show a spicular component composed of acanthostyles, acanthoxeas, and acanthostrongyles.

\section{Key to the Indo-Pacific Agelas species}

The present key is an attempt to discriminate between the Indo-Pacific species, but the scenario appears very intricate mainly because morphotraits from many descriptions and illustrations are overlapping (see Table 1). A similar attempt, on the Atlantic species, was performed by Parra-Velandia et al. (2014) emphasizing that: "Caribbean Agelas taxonomy rests heavily on the external morphology"; as a consequence their key is essentially based on growth form and colour. Since this is the situation, our key is not simply dichotomous and allows the disctintion of only 13 of the 17 Indo-Pacific species (see Appendix 1). The remaining four species have acanthostyles with length ranges which are widely overlapping (from less than 150 to more than $250 \mu \mathrm{m}$ ). Three 
of these (A. carpenteri, $A$. marmarica, and $A$. robusta) are known only from the original descriptions; on the contrary, $A$. mauritiana is reported by several authors but with discordant descriptions (Table 1).

1 Spicular complement composed by 1 or 2 spicular types (acanthoxeas, acanthostyles)

- Spicular complement composed by 3 spicular types (acanthoxeas, acanthostyles, acanthostrongyles)

A. sansibarica sp. n.

2 Spicular complement composed by 2 spicular types (acanthoxeas and acanthostyles)

- Spicular complement composed by 1 spicular type (acanthostyles) 4 Sponge body cup-shaped Sponge body blade-shaped A. axifera

- $\quad$ Sponge body lobed A. novaecaledoniae A. mauritiana oxeata

- $\quad$ Sponge body digitate A. dendromorpha

- $\quad$ Sponge body as slim cylindrical erected axis (branched or unbranched) A. gracilis

Acanthostyles of 2-dimensional categories .5

Acanthostyles of 1-dimensional category. .7

Long acanthostyles spiny only at the tips

A. semiglabra

Long and short acanthostyles almost entirely spiny

A. bispiculata

Primary and secondary fibres uncored. 8

Primary and/or secondary fibres cored . .9

Acanthostyles longer than $300 \mu \mathrm{m}$.

A. ceylonica

Acanthostyles length no more than $200 \mu \mathrm{m}$

A. cavernosa

9

Primary and secondary fibres cored A. nemoechinata Primary fibres cored and secondary uncored 10

10 Acanthostyles $(185-265 \times 8-15 \mu \mathrm{m})$ with $15-23$ whorls. Acanthostyles $(130-220 \times 4-21 \mu \mathrm{m})$ with 8-18 whorls. A. nakamurai

- $\quad$ Acanthostyles (80-370 × 5-24 $\mu \mathrm{m}$ ) with 11-33 whorls.

A. braekmani A. linnaei

\section{Acknowledgements}

We acknowledge financial support from EU-7FP, BAMMBO (Sustainable Production of Biologically Active Molecules of Marine Based Origin contract n. 265896), Regione Autonoma Sardegna (RAS2012-CRP60215 "Conservazione e valorizzazione delle grotte sarde: biodiversità e ruolo socio-economico-culturale"), Ministero dell'Istruzione, dell'Università e della Ricerca (MIUR-PRIN), and Fondazione Banco di Sardegna. We are grateful to the Swiss Marine NGO for specimen supply. We thank Nicole de Voogd and Zoölogische Mededelingen Leiden for Fig. 14 of Agelas linnaei. We are grateful to John Hooper and World Porifera Database for Fig. 6a of Agelas axifera. We are grateful to anonymous reviewers for their helpful comments and suggestions. 


\section{References}

Assmann M, Köck M (2002) Bromosceptrin, an alkaloid from the marine sponge Agelas conifera. Zeitschrift fur Naturforschung 57c: 157-160. doi: 10.1515/znc-2002-1-226

Assmann M, Lichte E, Pawlik JR, Köck M (2000) Chemical defenses of the Caribbean sponges Agelas wiedenmayeri and Agelas conifera. Marine Ecology Progress Series 207: 255-262. doi: 10.3354/meps207255

Assmann M, Zea S, Köck M (2001) Sventrin, a new bromopyrrole alkaloid from the Caribbean sponge Agelas sventres. Journal of Natural Products 64: 1593-1595. doi: 10.1021/ np010350e

Assmann M, Lichte E, Köck M (2004) Multiple defensive roles for bromopyrrole alkaloids from Caribbean Agelas sponges. In: Pansini M, Pronzato R, Bavestrello G, Manconi R (Eds) Sponge Sciences in the New Millennium, Bollettino dei Musei e degli Istituti Biologici dell'Università di Genova 68: 187-193.

Baer L (1906) Silicospongien von Sansibar, Kapstadt und Papeete. Archiv fur Naturgeschichte 72: 1-32, pl. i-v.

Bernan VS, Roll DM, Ireland CM, Greenstein M, Maiese WM, Steinberg DA (1993) A study on the mechanism of action of sceptrin, an antimicrobial agent isolated from the South Pacific sponge Agelas mauritiana. Journal of Antimicrobial Chemotherapy 32: 539-550. doi: $10.1093 / \mathrm{jac} / 32.4 .539$

Bickmeyer U (2005) Bromoageliferin and dibromoageliferin, secondary metabolites from the marine sponge Agelas conifera, inhibit voltage-operated, but not store-operated calcium entry in PC12 cells. Toxicon 45: 627-632. doi: 10.1016/j.toxicon.2005.01.006

Bickmeyer U, Assmann M, Köck M, Schütt C (2005) A secondary metabolite, 4,5-dibromopyrrole-2-carboxylic acid, from marine sponges of the genus Agelas alters cellular calcium signals. Environmental Toxicology and Pharmacology 19(3): 423-427. doi: 10.1016/j. etap.2004.12.003

Bickmeyer U, Drechsler C, Köck M, Assmann M (2004) Brominated pyrrole alkaloids from marine Agelas sponges reduce depolarization-induced cellular calcium elevation. Toxicon 44(1): 45-51. doi: 10.1016/j.toxicon.2004.04.001

Bickmeyer U, Grube A, Klings KW, Köck M (2008) Ageladine A, a pyrrole-imidazole alkaloid from marine sponges, is a $\mathrm{pH}$ sensitive membrane permeable dye. Biochemical and Biophysical Research Communications 373(3): 419-422. doi: 10.1016/j.bbrc.2008.06.056

Braekman JC, Daloze D, Stoller C, van Soest RWM (1992) Chemotaxonomy of Agelas (Porifera, Demospongiae). Biochemical Systematics and Ecology 20: 417-431. doi: 10.1016/0305-1978(92)90082-O

Carpenter WB (1856) The microscope and its revelations. Blanchard and Lea, Philadephia, $724 \mathrm{pp}$.

Carter HJ (1883) Contributions to our Knowledge of the Spongida. Annals and Magazine of Natural History (5) 12(71): 308-329, pls XI-XIV.

Chanas B, Pawlik JR, Lindel D, Fenical W (1996) Chemical defense of the Caribbean sponge Agelas clathrodes. Journal of Experimental Marine Biology and Ecology 208: 185-196. doi: 10.1016/S0022-0981(96)02653-6 
Costantino V, Fattorusso E, Imperatore C, Mangoni A (2006) Glycolipids from Sponges. Part 17. 1 Clathrosides and Isoclathrosides, Unique Glycolipids from the Caribbean Sponge Agelas clathrodes. Journal of natural products 69(1): 73-8. doi: 10.1021/np050331v

de Voogd NJ, Parra-Velandia FJ, Van Soest RWM (2008) A new Agelas (Demospongiae: Agelasida: Agelasidae) from the Thousand Islands, West-Java, Indonesia. Zoölogische Mededelingen Leiden 82(22): 235-243.

Dendy A (1905) Report on the sponges collected by Professor Herdman, at Ceylon, in 1902. In: Herdman WA (Ed.) Report to the Government of Ceylon on the Pearl Oyster Fisheries of the Gulf of Manaar. 3 (Supplement 18). Royal Society, London, 57-246, pls I-XVI.

Dendy A (1921) Report on the Sigmatotetraxonida collected by H.M.S. "Sealark" in the Indian Ocean. Transactions of the Linnean Society of London (ser. Zoology) 18(1): 1-164.

Ding N, Li C, Liu Y, Zhang Z, Li Y (2007) Concise synthesis of clarhamnoside, a novel glycosphingolipid isolated from the marine sponge Agelas clathrodes. Carbohydrate Research 342(14): 2003-2013. doi: 10.1016/j.carres.2007.05.018

Duchassaing De Fonbressin P, Michelotti G (1864) Spongiaires de la mer Caraïbe. Natuurkundige verhandelingen van de Hollandsche maatschappij der wetenschappen te Haarlem 21(2): 1-124, pls I-XXV.

Eder C, Proksch P, Wray V, van Soest RWM, Ferdinandus E, Pattisina LA, Sudarsono (1999) New bromopyrrole alkaloids from the Indopacific sponge Agelas nakamurai. Journal of Natural Products 62(9): 1295-1297. doi: 10.1021/np990071f

Fathi-Afshar R, Allen TM, Krueger CA (1989) Some pharmacological activities of novel adeninerelated compounds isolated from a marine sponge Agelas mauritiana. Canadian journal of physiology and Pharmacology 67(4): 276-281. doi: 10.1139/y89-045

Fattorusso E, Taglialatela-Scafati O (2000) Two novel pyrroleimidazole alkaloids from the Mediterranean sponge Agelas oroides. Tetrahedron Letter 41: 9917-9922. doi: 10.1016/ S0040-4039(00)01764-0

Ferretti C (2006) Aquaculture of two Mediterranean sponge species for bioactive molecules production. PhD thesis, Genoa University, $211 \mathrm{pp}$.

Ferretti C, Marengo B, De Ciucis C, Nitti M, Pronzato MA, Marinari UM, Pronzato R, Manconi R, Domenicotti C (2007) Effects of Agelas oroides and Petrosia ficiformis crude extracts on human neuroblastoma cell survival. International Journal of Oncology 30: 161-169. doi: 10.3892/ijo.30.1.161

Ferretti C, Vacca S, De Ciucis C, Marengo B, Duckworth AR, Manconi R, Pronzato R, Domenicotti C (2009) Growth dynamics and bioactivity variation of the Mediterranean demosponges Agelas oroides (Agelasida, Agelasidae) and Petrosia ficiformis (Haplosclerida, Petrosiidae). Marine Ecology 30(3): 1-10. doi: 10.1111/j.1439-0485.2008.00278.x

Fryday S (2011) A Study of Sponge Aquaculture in Jambiani: Is Shallow Farming Feasible? ISP Collection. Paper 1194. http://digitalcollections.sit.edu/isp_collection/1194

Fujita M, Nakao Y, Matsunaga S, Seiki M, Itoj Y, Yamashita J, van Soest RWM, Fusetani N (2003) Ageladine A An anti angiogenetic matrix metalloproteinase inhibitor from the marine sponge Agelas nakamurai. Journal of the American Chemical Society 125: 15700-15701. doi: $10.1021 / \mathrm{ja} 038025 \mathrm{w}$ 
Gray JE (1867) Notes on the Arrangement of Sponges, with the Descriptions of some New Genera. Proceedings of the Zoological Society of London 1867(2): 492-558, pls XXVII-XXVIII.

Hentschel E (1911) Tetraxonida. 2. Teil. In: Michaelsen W, Hartmeyer R (Eds) Die Fauna Südwest-Australiens. Ergebnisse der Hamburger südwest-australischen Forschungsreise 1905 3(10): 279-393.

Hertiani T, Edrada-Ebel R, Ortlepp S, van Soest RWM, de Voogd NJ, Wray V, Hentschel U, Kozytska S, Müller WEG, Proksch P (2010) From anti-fouling to biofilm inhibition: New cytoitoxic secondary metabolites from two Indonesian Agelas sponges. Bioorganic \& medicinal chemistry 18(3): 1297-1311. doi: 10.1016/j.bmc.2009.12.028

Hooper J, Van Soest RWM (2002) Systema Porifera. A Guide to the Classification of Sponges. vol. 1. Kluwer Academic/Plenum Publisher, New York, 1101 pp. doi: 10.1007/978-14615-0747-5_1

Hoshino T (1985) Description of two new species in the genus Agelas (Demospongiae) from Zamami Island, the Ryukyus, Japan. Proceedings of the Japanese Society of Systematic Zoology 30: 1-10, pls I-II.

Jenkin CF (1908) The calcareous sponges. The marine fauna of Zanzibar and British East Africa, from collection made by Cyril Crosland, M.A., in the years 1901 and 1902. Proceedings of the Zoological Society of London 1908: 434-456.

Keifer PA, Schwartz RE, Koker MES, Hughes RG Jr., Rittschof D, Rinehart KL (1991) Bioactive bromopyrrole metabolites from the Caribbean sponge Agelas conifera. The Journal of Organic Chemistry 56(9): 2965-2975. doi: 10.1021/jo00009a008

König GM, Wright AD (1993) Agelorins A and B, and 11-epifistularin-3, three new antibacterial fistularin-3 derivatives from the tropical marine sponge Agelas oroides. Heterocycles 36: 1351-1358. doi: 10.3987/COM-92-6317

König GM, Wright AD, Linden A (1998) Antiplasmodial and cytotoxic metabolites from the Maltese sponge Agelas oroides. Planta Medica 64: 443-447. doi: 10.1055/s-2006-957477

Laubenfels MW De (1954) The Sponges of the West-Central Pacific. Oregon State Monographs. Studies in Zoology 7: i-x, 1-306, pls I-XII.

Lendenfeld R Von (1897) Spongien von Sansibar. Abhandlungen herausgegeben von der Senckenbergischen naturforschenden Gesellschaft 21: 93-133, pls 9-10.

Lévi C (1958) Résultats scientifiques des Campagnes de la 'Calypso'. Campagne 1951-1952 en Mer Rouge (suite). 11. Spongiaires de Mer Rouge recueillis par la 'Calypso' (1951-1952). Annales de l'Institut océanographique 34(3): 3-46.

Lévi C (1961) Résultats scientifiques des Campagnes de la 'Calypso'. Campagne 1954 dans l'Océan Indien (suite). 2. Les spongiaires de l'Ile Aldabra. Annales de l'Institut océanographique 39(1): 1-32, pls 1-2.

Lévi C (1964) Spongiaires du canal de Mozambique. Bulletin du Muséum national d'Histoire naturelle, Ser. 2, 36(3): 384-395.

Lévi C (1967) Démosponges Récoltées en Nouvelle-Calédonie par la Mission Singer-Polignac. Expédition Française sur les récifs coralliens de la Nouvelle-Calédonie, Paris 2: 13-28, pls I-III.

Lévi C (1993) Porifera Demospongiae: Spongiaires bathyaux de Nouvelle-Calédonie, récoltés par le 'Jean Charcot'. Campagne BIOCAL, 1985. In: Crosnier A (Ed.) Résultats des cam- 
pagnes MUSORSTOM, Vol. 11. Mémoires du Muséum national d'Histoire naturelle (A, Zoologie) 158: 9-87.

Lévi C, Lévi P (1983) Démosponges bathyales récoltées par le N/O’ Vauban’ au sud de la Nouvelle-Calédonie. Bulletin du Muséum national d'Histoire naturelle (4, A) 5(4): 931-997.

Lévi C, Lévi P (1989) Spongiaires (MUSORSTOM 1 \& 2). In: Forest J (Ed.) Résultats des Campagnes MUSORSTOM, Vol. 4. Mémoires du Muséum national d'Histoire naturelle (A, Zoologie) 143: 25-103.

Meketa ML, Weinreb SM (2006) Total synthesis of ageladine A, an angiogenesis inhibitor from the marine sponge Agelas nakamurai. Organic Letter 30: 1443-1446. doi: 10.1021/ol0602304

Mordhorst T, Awal S, Jordan S, Petters C, Sartoris L, Dringen R, Bickmeyer U (2015) The Chemically Synthesized Ageladine A-Derivative LysoGlow84 Stains Lysosomes in Viable Mammalian Brain Cells and Specific Structures in the Marine Flatworm Macrostomum lignano. Marine Drugs 13(2): 920-935. doi: 10.3390/md13020920

Muricy G, Lopes DA, Hajdu E, Carvalho MS, Moraes FC, Klautau M, Menegola C, Pinheiro US (2011) Catalogue of Brazilian Porifera. Museu Nacional, Rio de Janeiro, 300 pp.

Murray PM, Moane S, Collins C, Beletskaya T, Thomas OP, Duarte AW, Nobre FS, Owoyemi IO, Pagnocca FC, Sette LD, McHugh E, Causse E, Perez-Lopez P, Feijoo G, Moreira MT, Rubiolo J, Leiros M, Botana LM, Pinteus S, Alves C, Horta A, Pedrosa R, Jeffryes C, Agathos SN, Allewaert C, Verween A, Vyverman W, Laptev I, Sineoky S, Bisio A, Manconi R, Ledda F, Marchi M, Pronzato R, Walsh DJ (2013) Sustainable production of biologically active molecules of marine based origin. New Biotechnology 30: 839-850. doi: 10.1016/j.nbt.2013.03.006

Parra-Velandia FJ, Zea S, Van Soest RWM (2014) Reef sponges of the genus Agelas (Porifera: Demospongiae) from the Greater Caribbean. Zootaxa 3794(3): 301-343. doi: 10.11646/ zootaxa.3794.3.1

Pulitzer-Finali G (1982) Some shallow water sponges from Hong Kong. In: Morton BS, Tseng CK (Eds) Proceedings 1st International Marine Biology Workshop, The Marine Flora and Fauna of Hong Kong and Southern China. Hong Kong University Press, 97-100.

Pulitzer-Finali G (1993) A collection of marine sponges from East Africa. Annali del Museo civico di Storia Naturale "Giacomo Doria” 89: 247-350.

Pulitzer-Finali G (1996) Sponges from the Bismarck Sea. Bollettino dei Musei e degli Istituti Biologici dell'Università di Genova 60-61: 101-138.

Regalado EL, Laguna A, Mendiola J, Thomas OP, Nogueiras C (2011) Bromopyrrole alkaloids from the Caribbean sponge Agelas cerebrum. Química Nova 34(2): 289-291. doi: 10.1590/ S0100-40422011000200022

Said SA, Moshi MJ, Nondo RSO, Masimba PJ, Innocent E, Guantai AN (2010) Evaluation of the potential of the marine sponges of the Zanzibar Island to yield antimalarial and antimicrobial active compounds. Tanzanian Journal of Health Research 12 (3): 195-202.

Sollas IBJ (1908) The inclusion of foreign bodies by sponges, with a description of a new genus and species of monoaxonida. Annals and Magazine of natural History 1(8): 395-401. doi: $10.1080 / 00222930808692424$

Thiele J (1903) Kieselschwämme von Ternate. II. Abhandlungen herausgegeben von der Senckenbergischen naturforschenden Gesellschaft 25: 933-968, pl. XVIII. 
Thomas PA (1973) Marine Demospongiae of Mahe Island in the Seychelles Bank (Indian Ocean). Annales du Musée royal de l'Afrique centrale. Sciences zoologiques 203: 1-96, pls $1-8$.

Thomas PA (1976) The history of spongology of the Indian Ocean. Journal of the Marine Biological Association of India 18(3): 610-625.

Thomas PA (1979) Studies on sponges of the Mozambique Channel. Annalen. Reeks in 8 Koninklijk Museum voor Midden-Afrika: zoologische wetenschappen, 227. Koninklijk Museum voor Midden-Afrika, Tervuren, Belgium, 73 pp., pl. 3.

Thomas PA (1981) A second collection of marine Demospongiae from Mahe Island in the Seychelles Bank (Indian Ocean). Annalen. Reeks in 8 - Koninklijk Museum voor Midden-Afrika: zoologische wetenschappen, 233. Koninklijk Museum voor Midden-Afrika, Tervuren, Belgium, 54 pp., pl. 4.

Thomas PA (1998) Sponges of Papua and New Guinea III Orders Poecilosclerida Topsent and Halichondrida Vosmaer. Journal of the Marine Biological Association of India 39(1-2): 148-154. doi: 10.1016/0077-7579(89)90016-1

Vacelet J, Vasseur P (1965) Spongiaires des grottes et surplombs des récifs de Tuléar (Madagascar). Recueil des Travaux de la Station marine d'Endoume 2-4: 71-123.

Vacelet J, Vasseur P (1971) Éponges des récifs coralliens de Tuléar (Madagascar). Téthys, Suppl. 1: 51-126.

Vacelet J, Vasseur P, Lévi C (1976) Spongiaires de la pente externe des récifs coralliens de Tuléar (Sud-Ouest de Madagascar). Mémoires du Muséum national d'Histoire naturelle (A, Zoologie) 49: 1-116, pls I-X.

Van Soest RWM (1989) The indonesian sponge fauna: a status report. Netherlands Journal of Sea Research 23(2): 223-230.

Van Soest RWM (2002) Family Agelasidae Verrill, 1907. In: Hooper J, Van Soest RWM (Eds) Systema Porifera. A Guide to the Classification of Sponges. vol. 1. Kluwer Academic/Plenum Publisher, New York, 819-820. doi: 10.1007/978-1-4615-0747-5_86

Van Soest RWM, Boury-Esnault N, Hooper JNA, Rützler K, de Voogd NJ, Alvarez de Glasby B, Hajdu E, Pisera AB, Manconi R, Schoenberg C, Janussen D, Tabachnick KR, Klautau M, Picton B, Kelly M, Vacelet J, Dohrmann M, Díaz MC, Cárdenas P (2015) World Porifera database. http://www.marinespecies.org/porifera

Vergne C, Appenzeller J, Ratinaud C, Martin M, Debitus C, Zaparucha A, Al-Mourabit A (2008) Debromodispacamides B and D: Isolation from the marine sponge Agelas mauritiana and stereoselective synthesis using a biomimetic proline route. Organic Letters 10(3): 493-496. doi: 10.1021/ol702866m

Vik A, Hedner EE, Charnock C, Samuelsen O, Larsson R, Gundersen LL, Bohlin L (2006) (+)-agelasine D: Improved synthesis and evaluation of antibacterial and cytotoxic activities. Journal of Natural Products 69: 381-386. doi: 10.1021/np050424c

Walker RP, Faulkner DJ, Van Engen D, Clardy J (1981) Sceptrin, an antimicrobial agent from the sponge Agelas sceptrum. Journal of the American Chemical Society 103: 6772-6773. doi: 10.1021/ja00412a052

Whitelegge T (1897) The Sponges of Funafuti. Memoirs of the Australian Museum 3: 323332, pl. XVIII. doi: 10.3853/j.0067-1967.3.1897.499 


\section{Appendix I}

Indo-Pacific species belonging to the genus Agelas reported from the literature.

\section{Agelas axifera Hentschel, 1911}

Fig. 6

Description (modified from Hentschel 1911). Growth form club-shaped $(12 \times 6 \mathrm{~cm})$, walls $0.5 \mathrm{~cm}$ in thickness. Surface irregular. Colour orange. Ectosomal skeleton not reported. Choanosomal skeleton irregularly reticulate network (meshes $320 \mu \mathrm{m}$ in diameter) of fibres echinated by few spicules. Primary fibres ( $80 \mu \mathrm{m}$ in diameter) cored by spicules. Secondary fibres ( $40 \mu \mathrm{m}$ in diameter) not cored. Megascleres verticillate of two categories. Acanthostyles and acanthoxeas of similar size (112-152 × 5-7 $\mu \mathrm{m})$ ornate by 7-15 regular whorls with 5-6 acuminate thorns each one. Habitat. Not reported. Geographic distribution. Pacific Ocean, Australia. Remarks. Type specimen stranded on beach at Champion Bay, Geraldton, Western Australia.
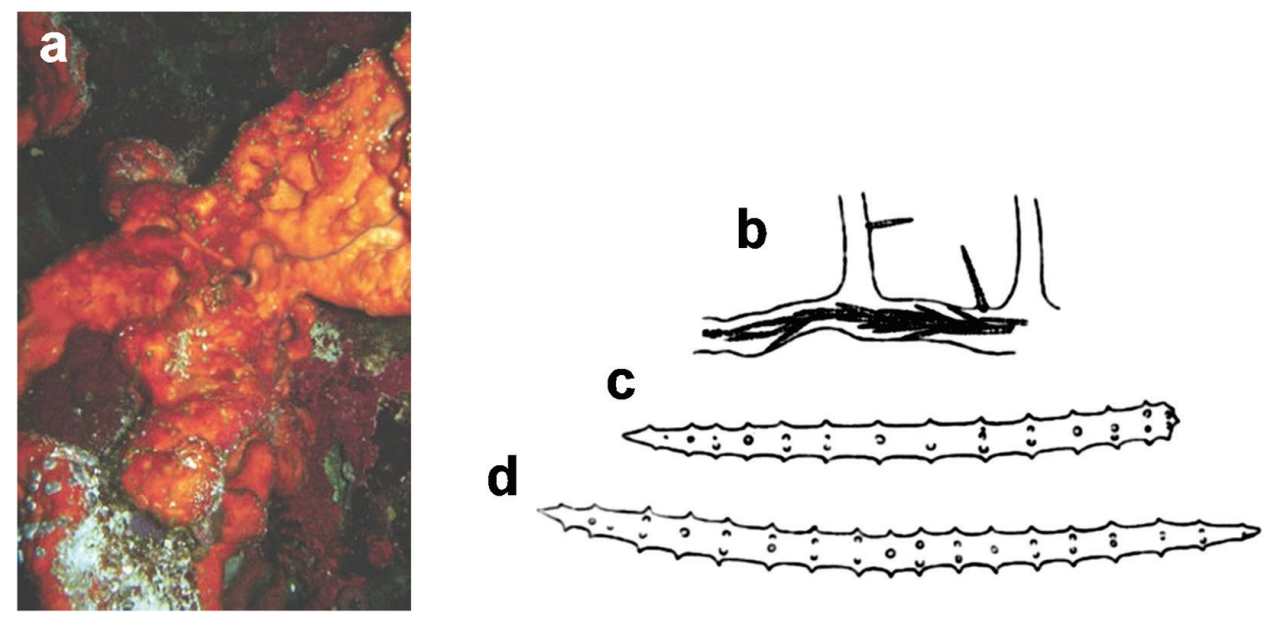

Figure 6. Agelas axifera. a living specimen $\mathbf{b}$ skeleton fragment with two spicular types, axially embedded in a fibre and arming the surface $\mathbf{c}$ acanthostyles $\mathbf{d}$ acanthoxea (a modified from an original underwater shot by J. Hooper b-d modified from Hentschel 1911).

\section{Agelas bispiculata Vacelet, Vasseur \& Lévi, 1976}

Fig. 7

Description (modified from Vacelet et al. 1976). Growth form massive; hemispherical fragments $(5-6 \mathrm{~cm}$ in diameter). Surface hispid. Oscules and pores not evident. 


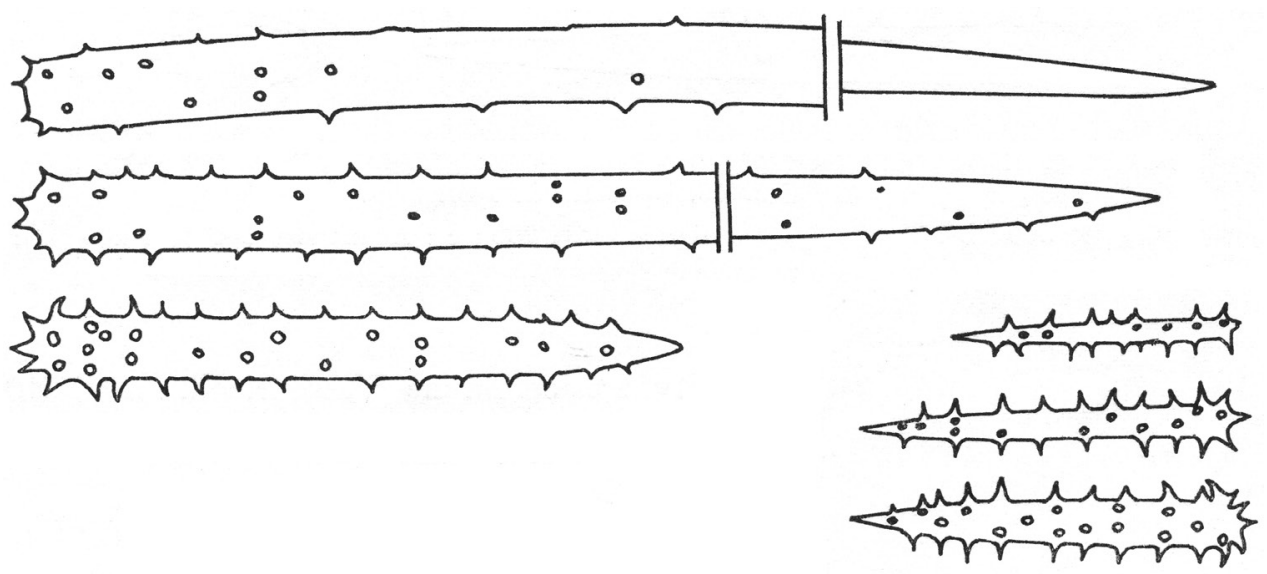

Figure 7. Agelas bispiculata. Spicular complement of acanthostyles of two size categories (modified from Vacelet et al. 1976).

Consistency elastic. Colour yellowish in spirit. Ectosomal skeleton not reported. Choanosomal skeleton as reticulate network of thick, armed spongin fibres. Primary fibres (70 $\mu \mathrm{m}$ in diameter) axially cored by large acanthostyles type I and echinated by small acanthostyles type II. Secondary fibres (40-50 $\mu \mathrm{m}$ in diameter) less abundant, without spicules. Megascleres of one category, acanthostyles of two dimensional classes. Acanthostyles type I $(320-400 \times 14-17 \mu \mathrm{m})$ ornate by 20 not accentuate whorls. Acanthostyles type II $(55-120 \times 6-10 \mu \mathrm{m})$ ornate by $11-15$ accentuate whorls. Habitat. Coral reefs, shade zone (caves, cavities). Geographic distribution. Western Indian Ocean. Recorded only from Mozambique Channel (eastern Madagascar). Remarks. de Voogd et al. (2008) focused on larger acanthostyles localized in the axial skeleton, and the smaller ones echinanting the fibres. Known only from the type locality, Grand Recife, Entsetreky (Tulear), Madagascar.

\section{Agelas braekmani Thomas, 1998}

Fig. 8

Description (modified from Thomas 1998). Growth form tubular and irregularly branched $10 \mathrm{~mm}$ in diameter, branches tips blind or with apical oscule $2-4 \mathrm{~mm}$ in diameter, or sometime bearing a funnel-shaped opening with an orifice $30 \mathrm{~mm}$ in diameter. Consistency stiff, cork-like. Foreign particles as shell pieces embedded on the wall at place. Surface hispid. Ectosomal skeleton as erected spicules supporting the dermal membrane. Choanosomal skeleton as reticulate network of spiculous spongin fibres, mesh size $180-560 \mu \mathrm{m}$. Primary fibres echinate and thick (up to $132 \mu \mathrm{m}$ in diameter) feeble cored by acanthostyles. Secondaries not cored, fairly common echinated by spicules $(42-76 \mu \mathrm{m})$. Megascleres verticillate of a single category. Acanthostyles 130-220 

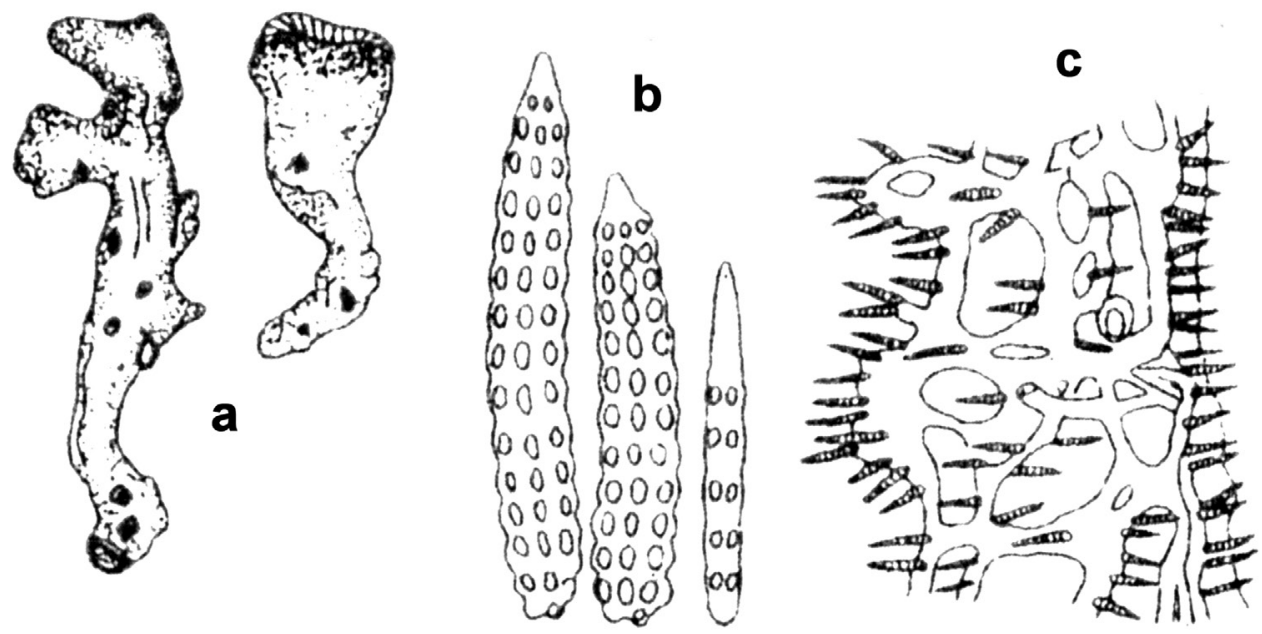

Figure 8. Agelas braekmani. a schematic drawings of two specimens b spicular complement of verticillate acanthostyles $\mathbf{c}$ skeleton architecture with echinate fibres, sponge surface on the right (modified from Thomas 1998).

(159) $\times 4-21 \mu \mathrm{m}(15 \mu \mathrm{m}$ excluding spines; up to $25 \mu \mathrm{m}$ with spines $)$ ornamented by verticillate spines arranged as $8-18$ whorls. Younger spicules partly annulated, each spine tubercled at the base. Habitat. Shallow water. Geographic distribution. Pacific Ocean. Recorded from Hansa Bay (type locality), Madang Province, Bismarck Sea. Remarks. This species was not considered in the revision by de Voogd et al. (2008).

\section{Agelas carpenteri (Gray, 1867)}

Fig. 9

Halichondria (?) Carpenter, 1856 in Gray (1867)

Ectyon carpenteri Gray, 1867

Description (modified from Gray 1867). Growth form massive. Ectosomal skeleton not reported. Choanosomal skeleton as a reticulate network of cylindrical spongin fibres echinated by single scattered spicules or groups of diverging spicules. Spicules fusiform, verticillate with $c a$. 10 whorls. Habitat. Not reported. Geographic distribution. Western Indian Ocean. Recorded only once from Madagascar. Remarks. This species is poorly described and illustrated. The spicule typology (oxeas or styles) are not reported by the author. Gray erected this species on the basis of what is shown by Carpenter (1856) in his book on microscopy. 


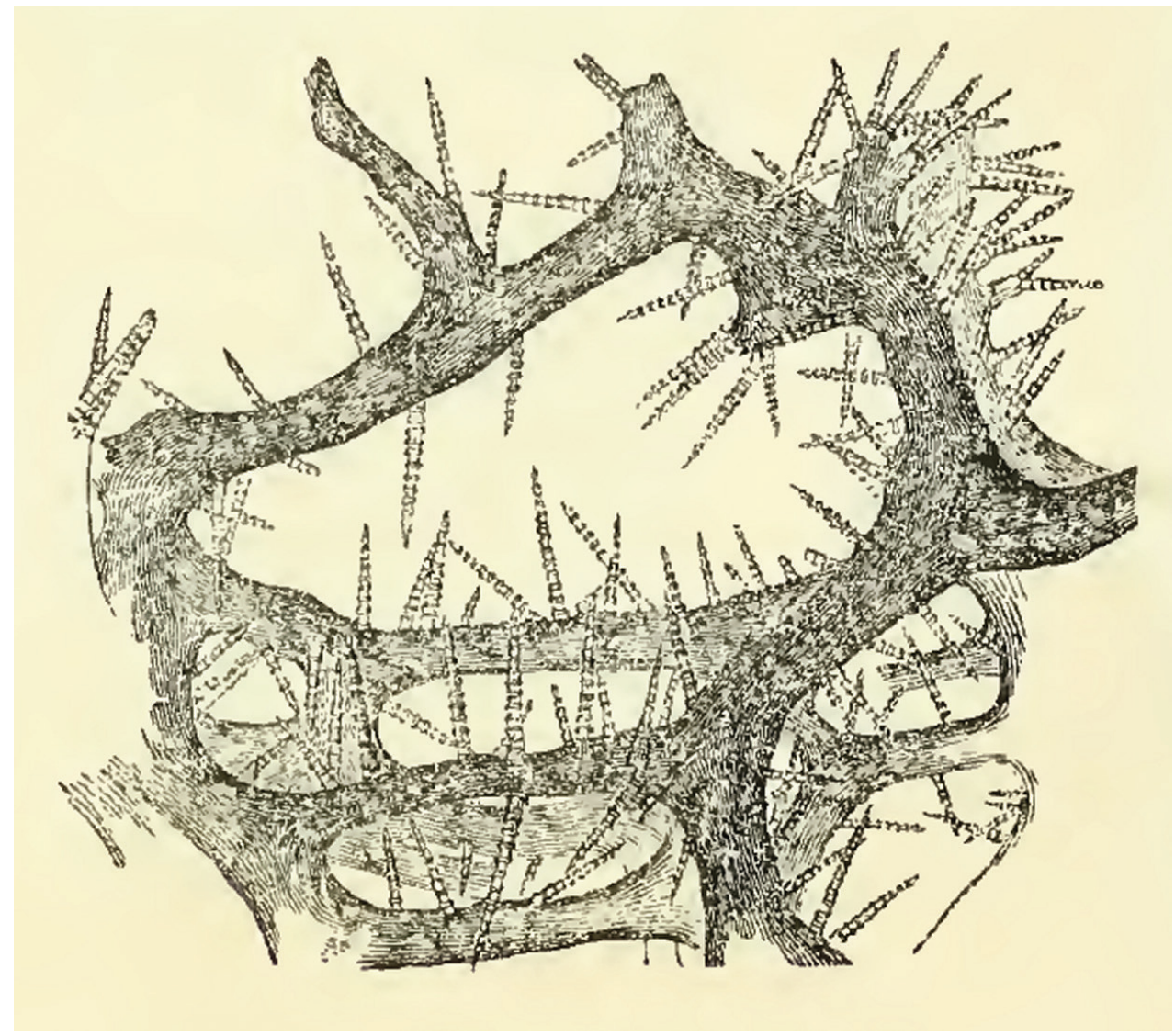

Figure 9. Agelas carpenteri. Drawing of the reticulate network with spongin fibres echinated by verticillate spicules perpendicularly arranged (modified from Carpenter 1856).

\section{Agelas cavernosa Thiele, 1903}

Fig. 10

Description (modified from Thiele 1903). Growth form irregularly massive with basal portion bearing digitiform outgrowths with a single, large oscule at the tips. Surface grainy with small stones or other foreign particulate. Colour blackish. Cavernous structure. Ectosomal skeleton not reported. Choanosomal skeleton as a dense network of brownish fibres. Fibres uncored, echinated by spicules. Megascleres of a single category. Acanthostyles $(200 \times 15 \mu \mathrm{m})$ verticillate, ornamented by 16 whorls of 15 spines each. Habitat. Tropical; not reported in detail. Geographic distribution. Ternate (type locality), Halmahera, Maluku Islands (Moluccas), eastern Indonesia. Remarks. The original description and particularly the illustration (only one spicule) are not exhaustive. 


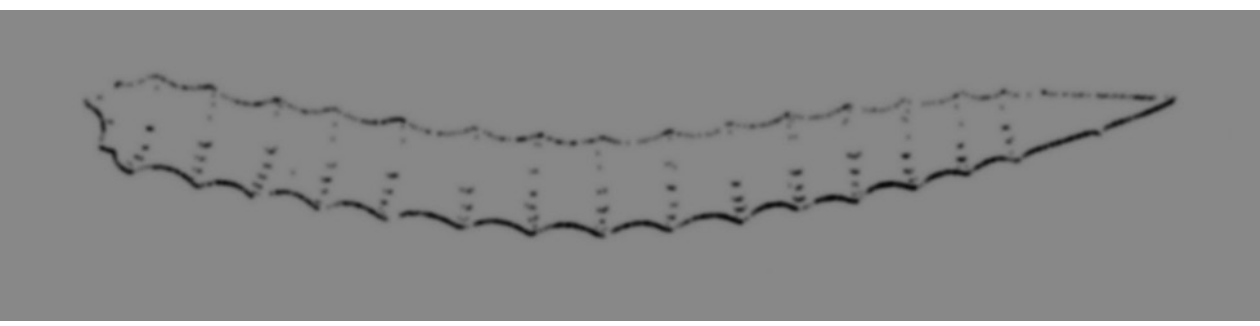

Figure 10. Agelas cavernosa. The original illustration of verticillate acanthostyles ornate by spiny whorls by Thiele (1903).
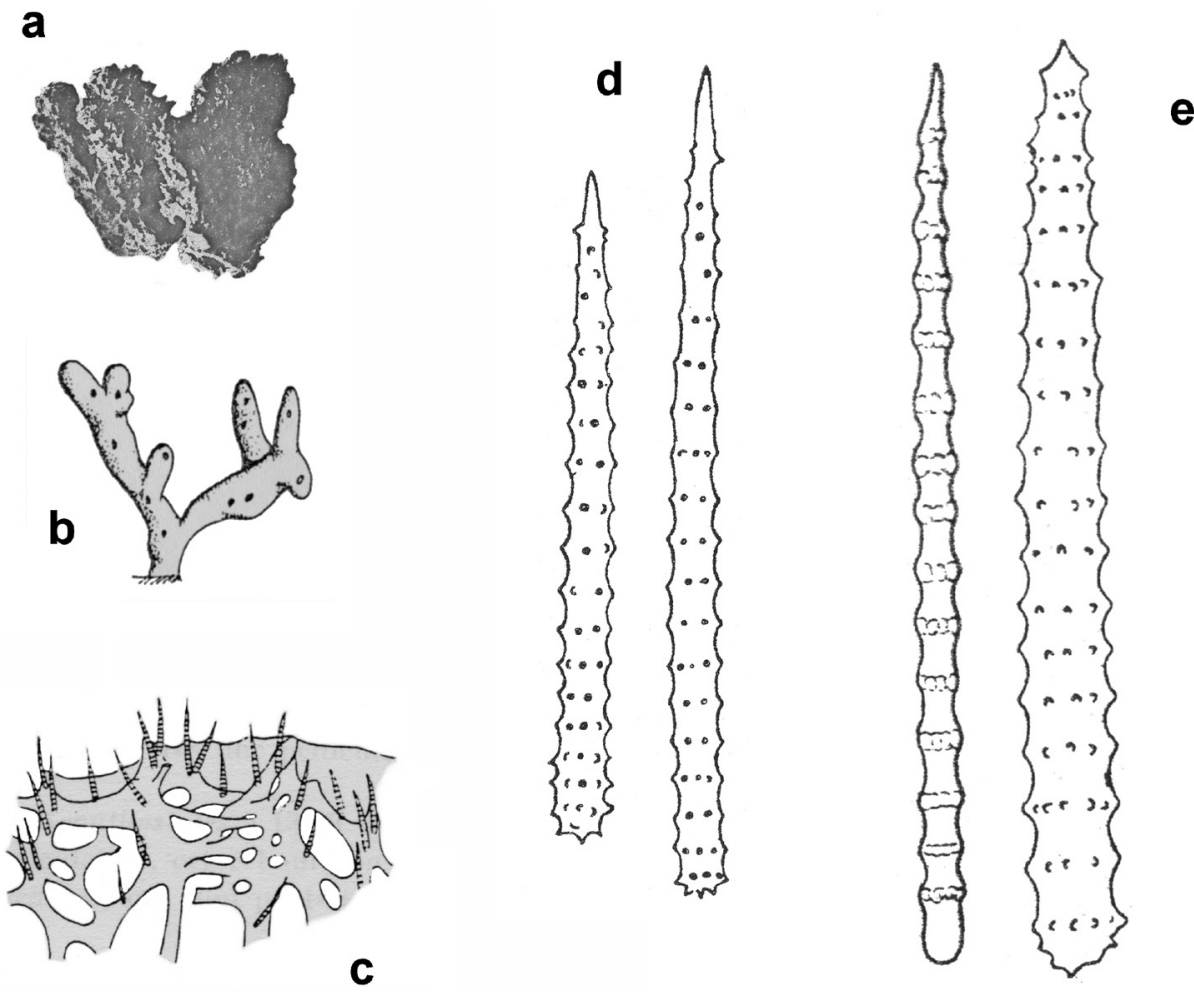

Figure I I. Agelas ceylonica. a very low quality image of the specimen studied by Dendy 1921 b schematic drawing of a branched specimen by Van Soest 1989 c skeleton architecture with echinate fibres d-e spicular complement of verticillate acanthostyles (c modified from Thomas $1981 \mathbf{d}$ modified from Dendy 1921 e modified from Lévi 1961).

\section{Agelas ceylonica Dendy, 1905}

Fig. 11

Description (modified from Dendy 1905, 1921, Lévi 1961, Thomas 1981). Growth form notably variable from ramose with slender subcylindrical digitiform branches with blunt tips (2-5 mm in diameter; $27 \mathrm{~mm}$ total height) to bushy, very irregular $60 \times 41 \times$ 
$40 \mathrm{~mm}$ (Lévi 1961) or encrusting $(20 \times 15 \mathrm{~mm}, 1-3 \mathrm{~mm}$ in thickness) with oscules and pores not evident (Thomas 1981). Surface minutely hispid by spicules, irregular, conulose due to sharp, blunt, minute conules resulting from the protruding tips of ascending fibres. Consistency compressible, quite soft, elastic, resilient, fibrous and fairly tough in spirit. Colour brown, dark brown in spirit (Dendy 1905, 1921), orange (Lévi 1961), pale gray (Thomas 1981). Ectosomal skeleton as erect spicules (Thomas 1981). Choanosomal skeleton irregular network of pale-coloured spongin fibres (30 $\mu \mathrm{m}$ in diameter) cored by spicules and abundantly echinated by acanthostyles. Ascending primary and secondary fibres not well defined (20-60 $\mu \mathrm{m}$ in diameter), never cored by spicules (Thomas 1981). Megascleres asbelonging to two categories of styles: spiny, very variably verticillate and smooth. Acanthostyles $240 \times 20 \mu \mathrm{m}$ (Dendy 1905, 1921), $80-275 \times 5-15 \mu \mathrm{m}$ with 16-21 verticilles and 100-300 × 6-15 $\mu \mathrm{m}$ with 13-23 verticilles (Lévi 1961), acanthostyles $(240 \times 2 \mu \mathrm{m})$ straight to slightly curved, with small, conic spines (Thomas 1981). Smooth styles $(320 \times 24 \mu \mathrm{m})$ less frequently present (Dendy 1921). Habitat. Not reported. Geographic distribution. Indian Ocean. Recorded from south India, Sri Lanka, Indonesia, and Seychelles. Remarks. Recently recorded from Indonesia (de Voogd et al. 2008). The latter authors report that acanthostyles in the Manaar Gulf (type locality) specimens have a maximum dimension of $240 \times 20 \mu \mathrm{m}$.

\section{Agelas dendromorpha Lévi, 1993}

Fig. 12

Description (modified from Lévi 1993). Growth form bush-like (30-35 × 15-40 mm) branched, with main stem $9-10 \mathrm{~mm}$ in height, $3 \mathrm{~mm}$ in diameter. Branches with terminal buds (2-3 $\mathrm{mm}$ in diameter). Dermal membrane hispidate. Ectosomal skeleton as small acanthostyles in the dermal membrane. Choanosomal skeleton dense with spongin fibres echinated by spicules at the end of the main column or branches. Megascleres of a single category with two dimensional classes. Acanthostyles I (130-260 × 10-12 $\mu \mathrm{m})$ abundant, slightly curved, verticillate by 12-18 irregular whorls. Acanthostyles II $(60-100 \times 3-4 \mu \mathrm{m})$ from the ectosome less abundant, with 8-9 less organized whorls. Habitat. Deep water, 245-275 m of depth. Geographic distribution. Western Pacific Ocean. Recorded only from the type locality in New Caledonia. Remarks. Also small oxea-like spiny spicules reported in original illustrations but not in descriptions. de Voogd et al. (2008) reported that verticillation is absent in smaller acanthostyles.

\section{Agelas gracilis Whitelegge, 1897}

Fig. 13

Description (modified from Whitelegge 1897, Lévi and Lévi 1989). Growth form subcylindrical, thin (2-3 $\mathrm{mm}$ in diameter; $25-75 \mathrm{~mm}$ in length) unbranched, settled 

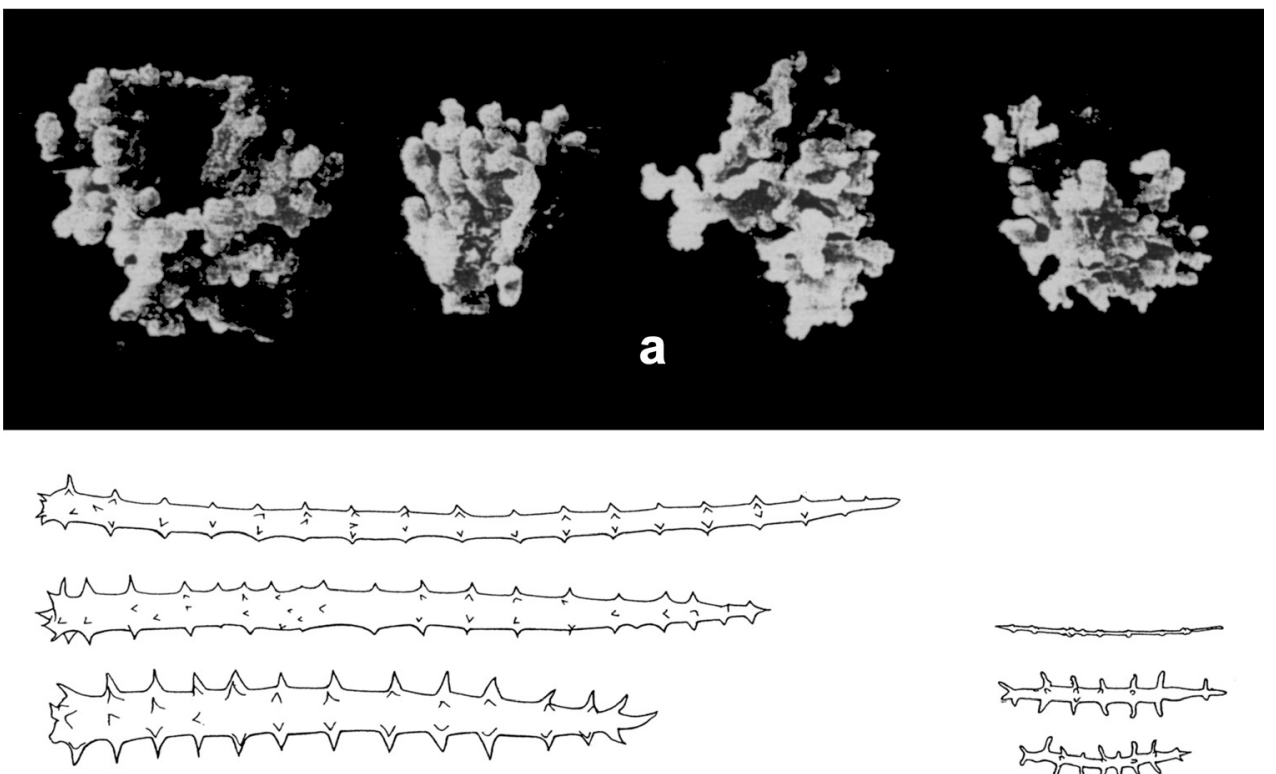

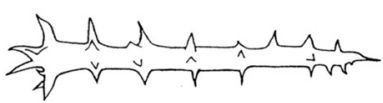

b

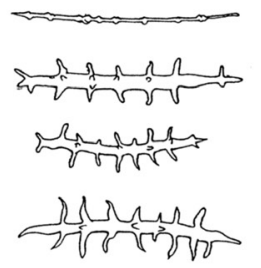

Figure 12. Agelas dendromorpha. $\mathbf{a}$ the sponge specimens of the type series $\mathbf{b}$ spicular complement of two spicular types, acanthostyles and acanthoxeas; small oxea-like spicules (bottom, right) are not reported in the original description (modified from Lévi 1993).
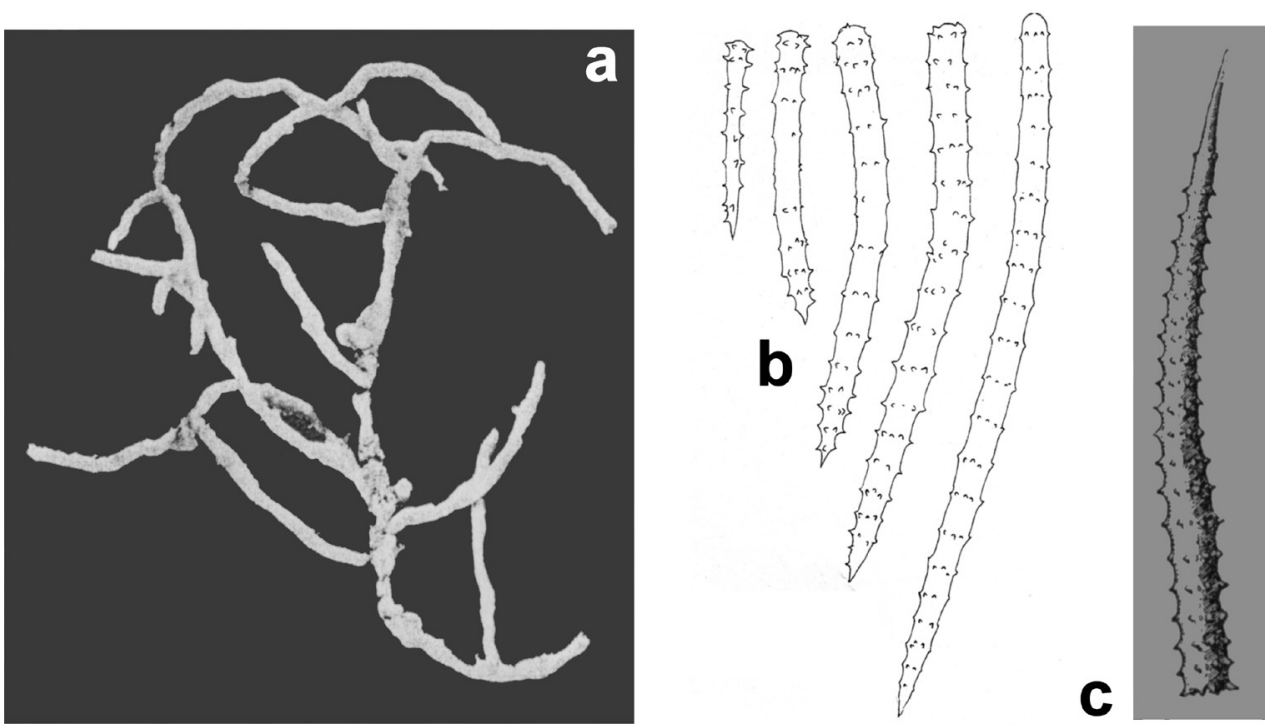

Figure 13. Agelas gracilis. a ramose slim dry specimen b-c spicular complement of verticillate acanthostyles of different dimensional categories (a-b modified from Lévi and Lévi 1983 c modified from Whitelegge 1897). 
on shells fragments. Surface uneven, hispid, with numerous minute conules $(0.2-0.5$ $\mathrm{mm}$ in height, $2-5 \mathrm{~mm}$ apart). A few minute pores between the conules. Consistency soft, spongy but also a bit tough. Colour greyish-yellow in spirit. Ectosomal skeleton not reported. Choanosomal skeleton network irregularly reticulate of spongin fibres, with oval or oblong mesh, rarely angular. Primary fibres $(70 \mu \mathrm{m}$ in diameter) with an axial plexus from which secondary ( $45 \mu \mathrm{m}$ in diameter) and tertiary fibres $(25 \mu \mathrm{m}$ in diameter) are given off. Megascleres of single category. Acanthostyles (100-220 × 7-13 $\mu \mathrm{m}$ ) verticillate by 16 to 24 whorls of small spines (Whitelegge 1897). Habitat. Coral reef, 72-125 m of depth. Geographic distribution. Western Pacific Ocean. Recorded from Funafuti and Philippines. Remarks. Lévi and Lévi (1989) reported branched growth form, fibres (20-30 $\mu \mathrm{m}$ in diameter), acanthostyles of two dimensional classes, type I 90-120 × 7-8 $\mu \mathrm{m}$ with 9-12 verticilles, and type II 190-290 $\times$ 8-13 $\mu \mathrm{m}$ with 17-21 verticilles. de Voogd et al. (2008) report that the specimen from the deeper subtidal (85-90 m) in the Philippines (Lévi and Lévi 1989) was ascribed to this species despite the divergence in spicular size.

\section{Agelas linnaei de Voogd, Parra-Velandia \& Van Soest, 2008}

Fig. 14

Description (modified from de Voogd et al. 2008). Growth form roundly lobate to thickly flabellate ( $8 \mathrm{~cm}$ in height, $2.5 \mathrm{~cm}$ in diameter). Consistency very soft, spongy. Colour bright orange at the surface to cream-orange internally. Surface with dense conules (1-3 $\mathrm{mm}$ in height) supported by tips of ascending fibres covered by a bright easily distinguishable membrane. Small apertures $(<2 \mathrm{~mm})$ scattered on the surface, bigger pores $(2-3 \mathrm{~mm})$ connected to internal axial canals sometime present between some lobes. Choanosome dense with narrow canals (primary canals $200 \mu \mathrm{m}-2.00 \mathrm{~mm}$ in diameter; secondary canals $100 \mu \mathrm{m}-1.00 \mathrm{~mm}$ in diameter). Ectosomal skeleton not reported. Choanosomal skeletal network irregularly and densely reticulate; primary fibres $(35-80 \mu \mathrm{m}$ in diameter) aggregated in packs, more or less undulated, heavily cored (1-7 spicules in cross section) and echinate; secondary fibres $(25-40 \mu \mathrm{m}$ in diameter) not cored and less echinate. Megascleres of a single category. Acanthostyles (78.7-(187)-372.3 × 5.2-(12.1)-24 $\mu \mathrm{m})$ straight, a few slightly curved, ornate by $11-$ (19.3)-33 whorls with 5-12 spines each; whorls conspicuous in the spicule centre but sometimes faint and irregular at the spicule tip and head. Habitat. Coral reef, overgrowing other reef invertebrates. Geographic distribution. Recorded from the Thousands Islands Reef complex, off Jakarta, West Java, Indonesia. Type locality: Peniki Island and Payang Island. Remarks. de Voogd et al. (2008) focused on the whorl measurements performed in the middle third of the spicule because spine abundance is dependent upon the width. This is a useful rule to perform uniform measurements of whorls in verticillate spicules. 

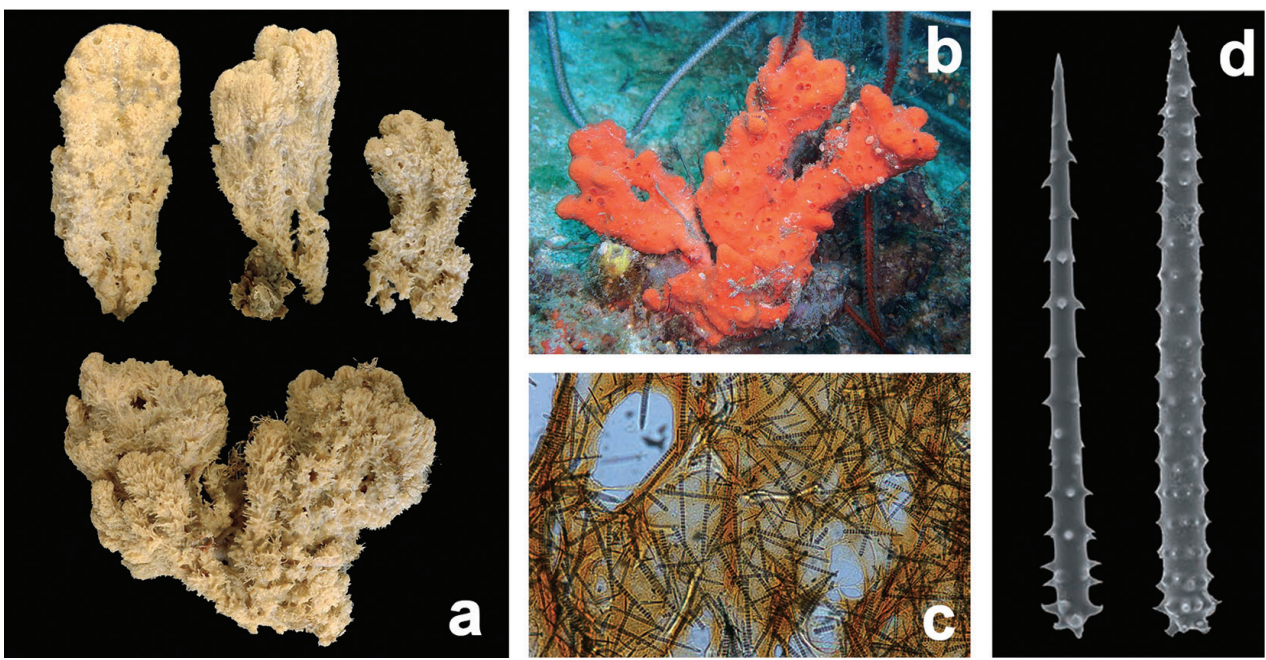

Figure 14. Agelas linnaei. a type series specimens (liquid preserved) b a living shallow water specimen c spongin skeleton with spicules $\mathbf{d}$ verticillate acanthostyles (modified from de Voogd et al. 2008).

\section{Agelas marmarica Lévi, 1958}

Fig. 15

Description (modified from Lévi 1958, Vacelet and Vasseur 1965, Vacelet and Vasseur 1971). Growth form not recorded. Colour orange to/or bright red. Ectosomal skeleton not reported. Choanosomal skeleton as a reticulate network of fibres $<30 \mu \mathrm{m}$ in diameter. Megascleres of a single category. Acanthostyles $(230 \times 10 \mu \mathrm{m})$ verticillate by 19-21 whorls of spines (Lévi 1958). Acanthostyles type I 100-270 × 7-14 $\mu \mathrm{m}$ with 21-25 whorls; acanthostyles type II 160-215 × 7-20 $\mu \mathrm{m}$ with 16-24 whorls (Vacelet and Vasseur 1965). Habitat. Coral reef, 20-30 m of depth. Geographic distribution. Indian Ocean. Recorded from Mozambique Channel (Madagascar) and Red Sea. Type locality: Saudi Arabian Red Sea. Remarks. Spicules morph and their sizes are very variable in descriptions and illustrations of different authors.

\section{Agelas mauritiana (Carter, 1883)}

Fig. 16, Table 1

\section{Ectyon mauritiana Carter, 1883}

Description (modified from Carter 1883, Thiele 1903, Dendy 1905, Laubenfels 1954, Lévi 1961, 1964, 1967, Vacelet and Vasseur 1965, 1971, Thomas 1979, 1998). Growth form highly variable: encrusting, tubular, massive, sometimes cavernous (Table 1) also ramose or massively branched $4.5 \mathrm{~cm}$ in height bearing five blunt branches $2 \mathrm{~cm}$ in di- 


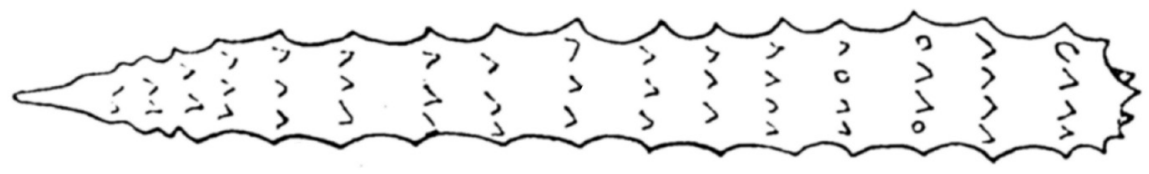

a
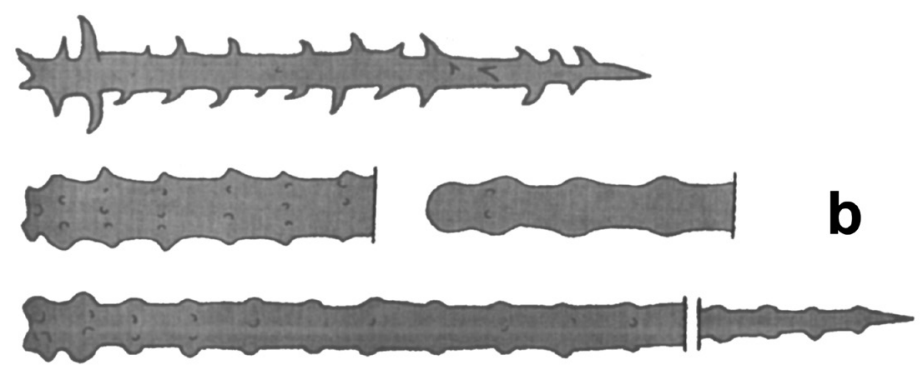

Figure 15. Agelas marmarica. a-b spicular complement (a modified from Vacelet and Vasseur 1965 b modified from Lévi 1958).

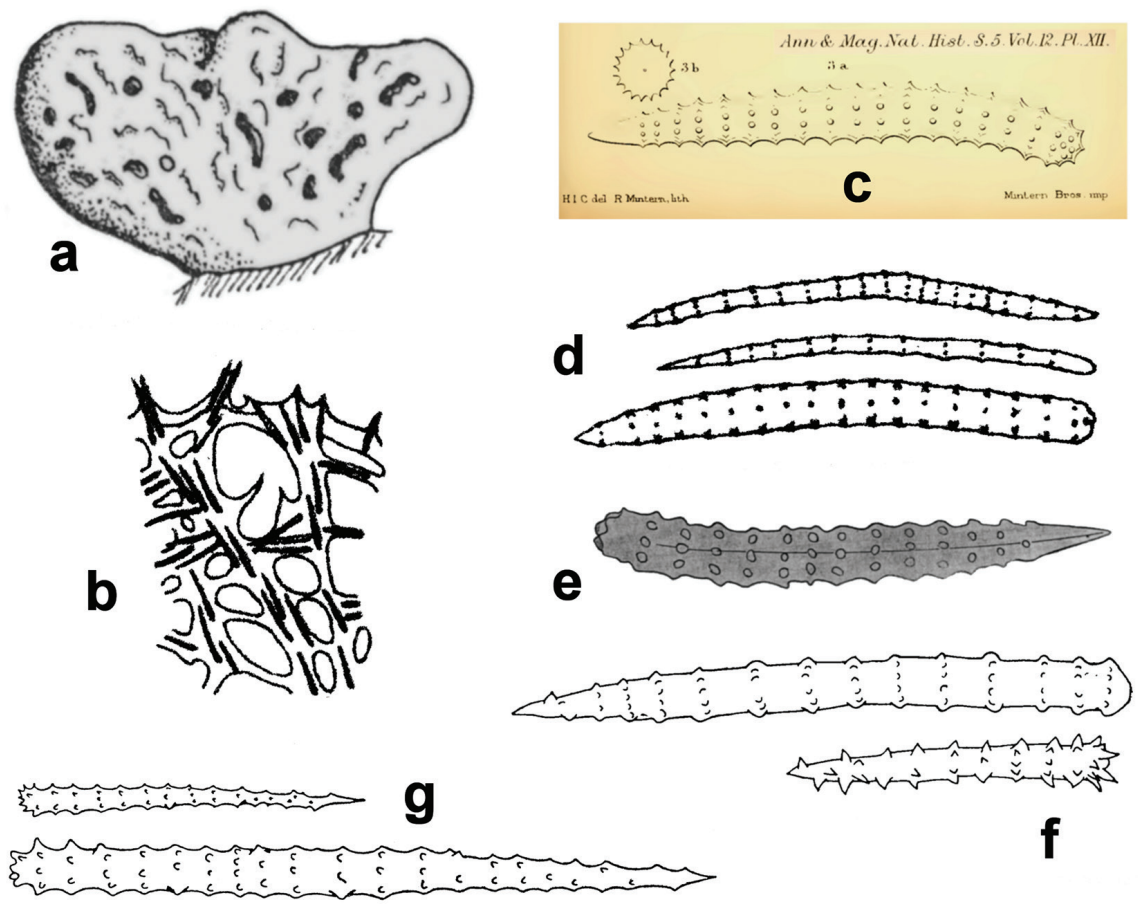

Figure 16. Agelas mauritiana. a drawing of a massive specimen $\mathbf{b}$ skeleton fragment $\mathbf{c}-\mathbf{g}$ spicular complement b-d A. mauritiana var. oxeata a modified from Van Soest 1989; b-d modified from Thomas 1979 c modified from Carter 1883 e modified from Vacelet and Vasseur $1965 \mathbf{f}$ modified from Lévi 1964 g modified from Lévi 1961). 
ameter with a circular oscule at the tip. Surface with raised oscules $2-3 \mathrm{~mm}$ in diameter (Lévi 1961, Vacelet and Vasseur 1971). Consistency firm, resilient coriaceus, but also soft, compressible. Colour notably variable (Table 1). Surface distinctly conulose at growing portions, older ones smooth and glabrous (Thomas 1979). Ectosomal skeleton not reported. Choanosomal skeleton as a dense, irregularly reticulate network of stout fibres very abundantly echinated (Dendy 1905, Lévi 1961, Thomas 1979). Primaries and secondary fibres amber -coloured and not differentiated from each other (Thomas 1979). Megascleres as verticillate acanthostyles of two size classes. Acanthostyles 130-275 × 8-20 $\mu \mathrm{m}$ with 10-20 whorls (Table 1). Smaller acanthostyles also reported (Table 1). Habitat. Not reported. Geographic distribution. Indian Ocean and West Pacific. Mascarene Archipelago (Mauritius is the type locality) and Seychelles Archipelago (Aldabra), Madagascar, Mozambique, Gulf of Aden, southern Red Sea, Gulf of Aqaba, Sri Lanka, and Australia. Remarks. Variable morphometries are reported by different authors (Table 1).

\section{Agelas mauritiana var. oxeata Lévi, 1961}

Fig. 16

Description (modified from Lévi 1961). Growth form lobed, each of the two lobes measures $20 \mathrm{~mm}$ in length and $8 \mathrm{~mm}$ in diameter. Colour brownish-red. Surface velvety. Choanosomal skeleton of primaries fibres cored by oxeas. Megascleres (100-220 $\times 4-18 \mu \mathrm{m})$ of two categories. Acanthostyles verticillate with 14-16 whorls. Acanthoxeas verticillate with 20-24 whorls. Habitat. Shallow water, 12 m of depth. Geographic distribution. Indian Ocean. Recorded only from Aldabra Island (type locality) in the Seychelles Archipelago. Remarks. This variety was not considered in the revision by de Voogd et al. (2008).

\section{Agelas nakamurai Hoshino, 1985}

Fig. 17

Description (modified from Hoshino 1985). Growth form massive, rounded or thickly encrusting. Colour orange rufous to brick red at the surface in dry specimens. Surface smooth, uneven, with irregularly meandering surface grooves. Consistency firmly spongy, resilient when wet; very hard, hardly compressible when dry. Ectosomal skeleton armed by tangential acanthostyles irregularly distributed. Choanosomal skeleton as a reticulate network with elliptical meshes (40-200 $\mu \mathrm{m}$ in diameter) of primary ascending spongin fibres and secondaries. Primary fibres $(70-100 \mu \mathrm{m}$ in diameter) cored by $4-8$ acanthostyles, and echinated by the same acanthostyles. Secondary fibres (20-70 $\mu \mathrm{m}$ in diameter) not cored, in places echinated by acanthostyles. Megascleres of a single category. Acanthostyles $185-(226)-267 \times 8-(12)-15 \mu \mathrm{m}$, straight to slight- 

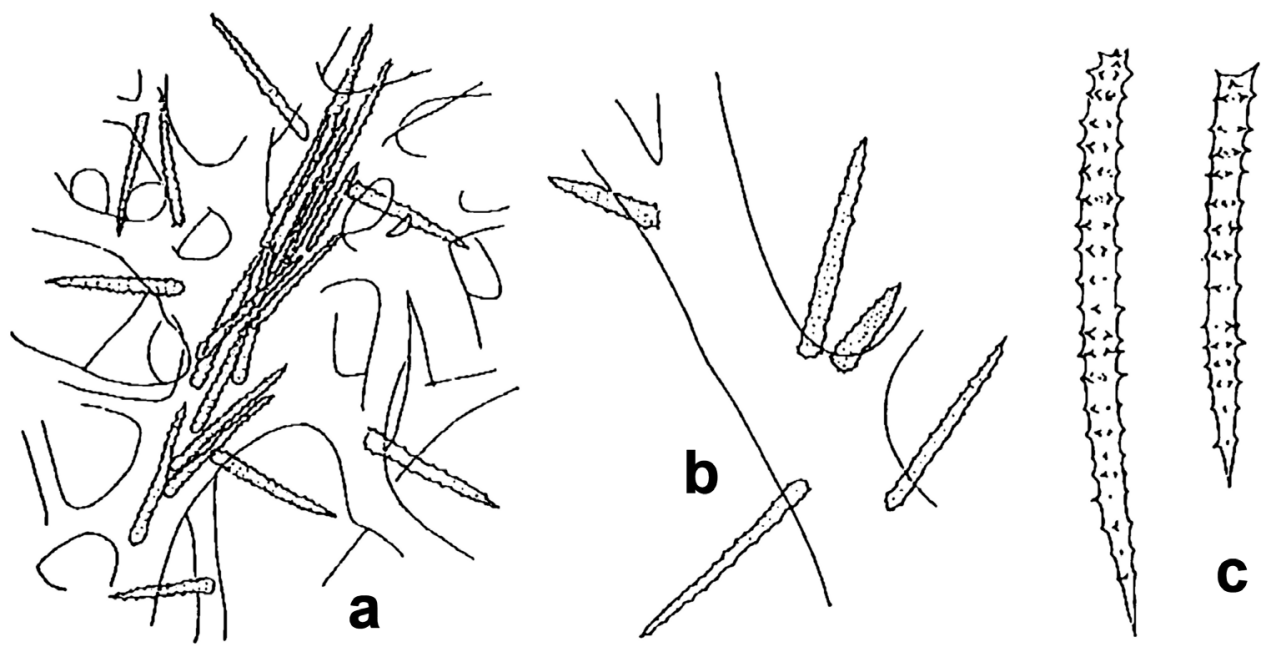

Figure 17. Agelas nakamurai. a skeleton architecture $\mathbf{b}$ close up of spicules insertion in the spongin fibres c acanthostyles (modified from Hoshino 1985).

ly curved, ornate by 15-23 whorls with eight spines each. Habitat. Shallow water, $20 \mathrm{~m}$ depth. Geographic distribution. Pacific Ocean. South Kuroshio, east Japan. Zamami Island (type locality), Ryukyu Archipelago, Japan. Remarks. Also recorded from Indonesia (de Voogd et al. 2008).

\section{Agelas nemoechinata Hoshino, 1985}

Fig. 18

Description (modified from Hoshino 1985). Growth form massive or thickly encrusting.

Consistency spongy, resilient when wet, hard and difficult to compress when dry. Colour madder brown at the surface to rufous-orange in the interior when dry. Oscules from $1-3$ to 5-8 $\mathrm{mm}$ in diameter. Ectosomal skeleton not reported. Choanosomal skeleton reticulate network with elliptical meshes (50-250 $\mu \mathrm{m}$ in diameter) of spongin fibres. Primary and secondary fibres almost indistinguishable $(20-50 \mu \mathrm{m}$ in diameter) and cored by 1-3 acanthostyles, occasionally not cored, only slightly echinated. Megascleres verticillate of a single category. Acanthostyles 170-(189)-210 $\times 9-(11)-13 \mu \mathrm{m}$, straight to gently curved, ornate by 16-23 regular whorls, each with eight spines. Habitat. Shallow water, $20 \mathrm{~m}$ depth. Geographic distribution. North Pacific Ocean. Recorded from south Kuroshio (east Japan). Type locality: Zamami Island, Ryukyu Archipelago. Remarks. Also recorded from Indonesia (de Voogd et al. 2008). These authors report acanthostyles occasionally sharply pointed at both ends (oxeas), as previously reported also in the original figures. 

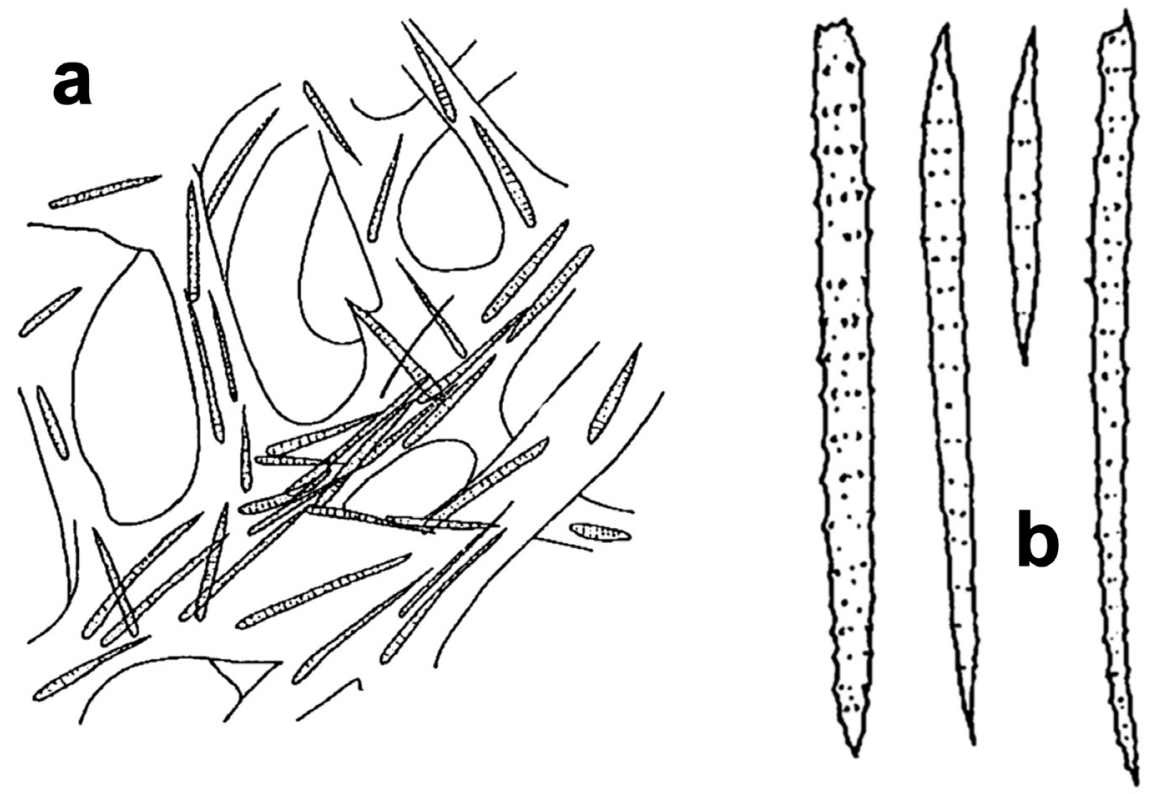

Figure 18. Agelas nemoechinata. a skeleton architecture b spicular complement (modified from Hoshino 1985).

\section{Agelas novaecaledoniae Lévi \& Lévi, 1983}

Fig. 19

Description (modified from Lévi and Lévi 1983). Growth form as a thick blade (18 $\mathrm{cm}$ in height, $12.5 \mathrm{~cm}$ in diameter, $1-4 \mathrm{~cm}$ in thickness). Consistency elastic. Colour ochre brown. Surface irregularly cavernous and strongly hispid. Oscules $(2-3 \mathrm{~mm}$ in diameter) numerous, 3-8 mm apart. Ectosomal skeleton armed by spicules. Choanosomal skeleton as a reticulate network of fibres $(100 \times 20 \mu \mathrm{m}$ in diameter $)$ laminar and fibrillar, rarely echinate at the sponge basal portion. Megascleres of two categories. Acanthostyles 100-190 × 5-8 $\mu \mathrm{m}$ (7-10 with spines) straight or slightly curved, verticillate by $12-17$ whorls of spines. Acanthoxeas slightly curved $(120-250 \times 5 \mu \mathrm{m})$ verticillate by 12-18 whorls of spines. Habitat. Deep water, 390-395 m of depth. Geographic distribution. Pacific Ocean. Recorded from New Caledonia. Remarks. Known only from the type locality.

\section{Agelas robusta Pulitzer-Finali, 1982}

Fig. 20

Description (modified from Pulitzer-Finali 1982). Growth form encrusting $(5 \mathrm{~mm}$ in thickness) to massive, roundish $(6 \times 3 \mathrm{~cm}$ in diameter). Cavernous (clathrous) structure, 

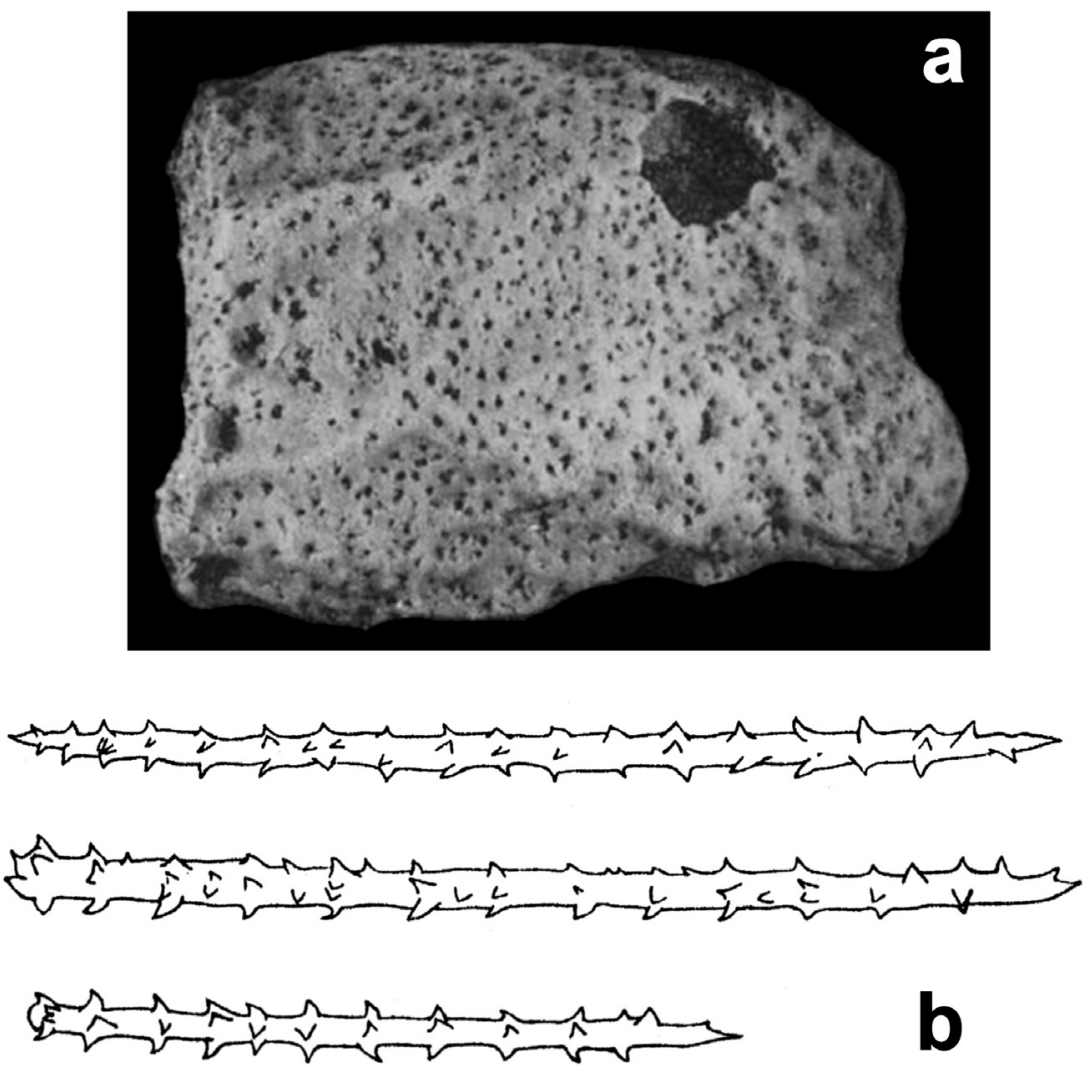

Figure 19. Agelas novaecaledoniae. a type specimen b spicular complement with two spicular types (modified from Lévi and Lévi 1983).

with narrow channels through the entire sponge. Consistency tough and resilient. Colour dull orange, dull yellowish-brown. Ectosomal skeleton not reported. Choanosomal skeleton reticulate with irregular meshes of pale spongin fibres $(38-80 \mu \mathrm{m}$ in diameter) abundantly echinate by acanthostyles. Megascleres of a single category. Acanthostyles very stout, verticillate $(170-250 \times 14-30 \mu \mathrm{m}$ spine included) with 11-12 whorls of short, blunt spines. Habitat. Not reported. Geographic distribution. Pacific Ocean. Recorded from Hong Kong, Southern China. Remarks. Known only from the type locality. At present for this species only three slides are available after damaging of type materials during the recent Genova flood in 2014 (October).

\section{Agelas semiglabra Pulitzer-Finali, 1996}

Fig. 21

Agelas semiglaber Pulitzer-Finali, 1996 

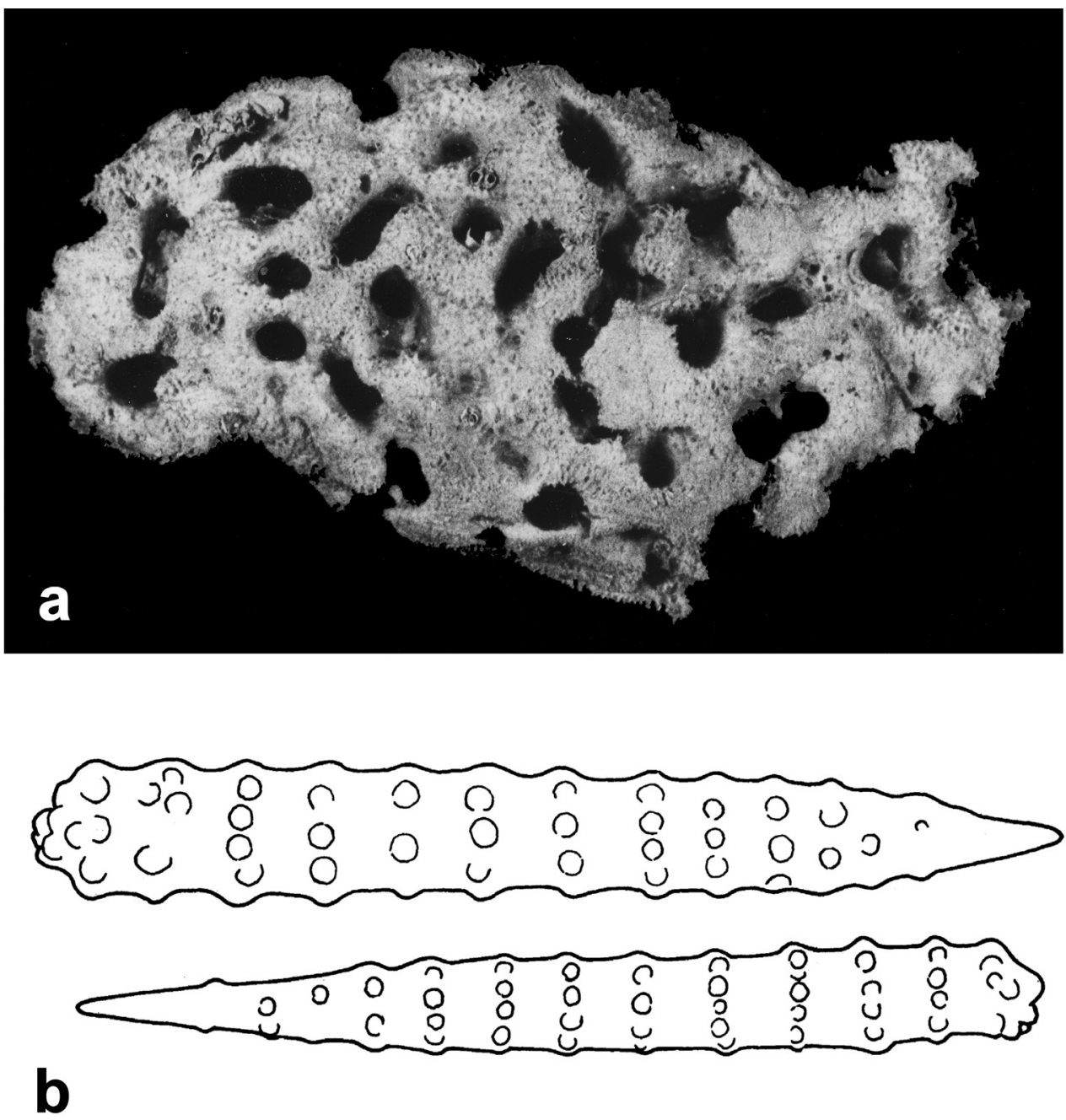

Figure 20. Agelas robusta. a type specimen (dry) b spicular complement of acanthostyles very stout, verticillate by blunt spines (modified from Pulitzer-Finali 1982).

Description (modified from Pulitzer-Finali 1996). Growth form encrusting, very small. Skeleton architecture not reported. Megascleres of single category and two size classes. Acanthostyles type I verticillate $(230-375 \times 11-16 \mu \mathrm{m})$, spiny only towards the tips. Acanthostyles type II $(75-100 \times 3.5 \mu \mathrm{m})$ verticillate, entirely spiny. Habitat. Shallow water. Geographic distribution. Pacific Ocean. Recorded from Bismarck Sea, known only from Papua New Guinea (type locality). Remarks. The specific epithet ending with $-e r$ is masculine despite the gender Agelas is feminine, as a consequence the ending must be changed into - ra. Because of the overlap in spicule dimension de Voogd et al. (2008) report that is not possible to distinguish different size categories. 


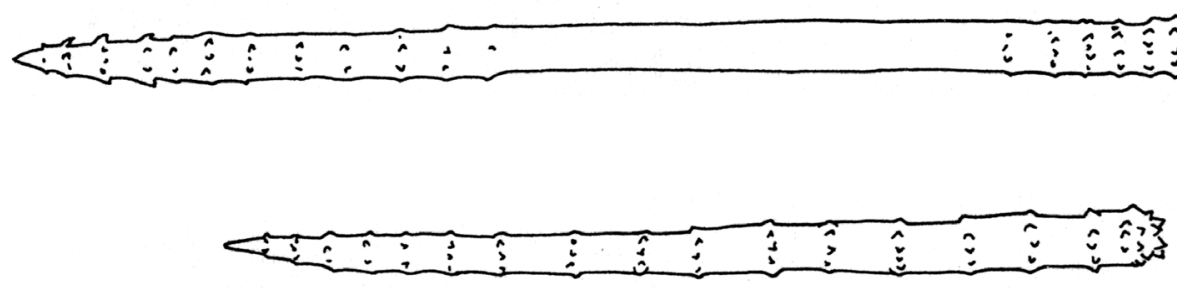

Figure 21. Agelas semiglabra. Spicular complement with two dimensional categories of acanthostyles; long acanthostyles spiny only at the tips (modified from Pulitzer-Finali 1996).

\section{Agelas spp.}

Several findings from the Seychelles Archipelago (Thomas 1973) and Kenya (PulitzerFinali 1993). The revisitation of the 11 Agelas specimens slides of the Pulitzer-Finali collection from East Africa highlighted the presence of only styles in the spicular complement with notable variability of thickness, length, and spinosity. This confirms his opinion: 'It would be inappropriate at the moment to try to identify some of them with established species and to propose new species.' Also in this case the original material is not available after damaging of types during the recent Genova flood in 2014 (October). 